\title{
Inter-modal Network Externalities and Transport Development: Evidence from Roads, Canals, and Ports during the English Industrial Revolution
}

\author{
Dan Bogart ${ }^{1}$ \\ Department of Economics, UC Irvine \\ 3151 Social Science Plaza \\ Irvine CA 92697-5100 \\ dbogart@uci.edu
}

\begin{abstract}
How does the development of one transport mode influence the development of another? This paper uses time-series data to test whether inter-model network externalities influenced the development of road, canal, and port infrastructure in England from 1760 to 1830. The main finding is that road development had a positive effect on canal development. The results suggest that the option value of investing in a canal in the future diminished when nearby road improvements were initiated because there was less uncertainty about future profits from canal tolls. They also suggest a reinterpretation of road transport in the Industrial Revolution and point to the general importance of intermodal network externalities.
\end{abstract}

Keywords: Inter-modal network externalities; British transport; Industrial Revolution JEL Classifications: R40, R50, N73

\footnotetext{
${ }^{1}$ I would like to thank David Levinson and Gary Richardson for providing helpful comments on earlier drafts. I would also like to thank Patricia Suzuki for providing valuable research assistance.
} 
Transportation networks serve a vital function in any economy by bringing finished goods to market, raw materials to firms, and people to work or leisure activities.

Therefore, the evolution of transport networks is of vital importance for the evolution of the economy. The literature has shown that the size and density of transport networks is partly a function of economic and financial development, but there is less agreement on the influence of other factors. ${ }^{2}$ For example, it is widely recognized that transport networks consist of different modes, like roads, railroads, water, and air travel, but we know little about how the development of one mode influences the others. Inter-modal network externalities can arise because some goods are shipped via several modes. For example, goods might enter through a port before being shipped by road, rail, or inland waterways to a market. If the port is too small, then goods will have difficulties reaching road, rail, and inland waterway networks, making them less valuable to users. Similarly, if road, rail, and inland waterway networks are underdeveloped, then the port will be less valuable to users as well.

Inter-modal network externalities are also linked with congestion effects. Delays can occur when passengers and freight share the same mode or when high-value freight shares the same mode as low-value freight. An expansion in road or airport networks might reduce delays on water or rail networks because passengers or high-value freight would then shift to roads or air. Similarly an expansion in water or rail networks might reduce delays on roads and in the air.

In this paper, I use history to examine the influence of inter-modal network externalities on transport development. Before the arrival of railways in the 1830s,

\footnotetext{
2 The role of economic and financial development in promoting transport networks is stressed throughout the literature. See Banister and Berechman (2000) for a recent summary.
} 
England's roads, rivers, and canals connected major cities and linked urban areas with their agricultural hinterlands and natural resources, like coal and iron. England's coastline was also well-served by ports, where ships of all sizes could unload food and coal before reloading cotton textiles and iron wares for export. Most of the roads, ports, and canals were built or improved between 1760 and 1830, at the same time as the Industrial Revolution. Each road, port, and canal project was authorized through an act of Parliament, which granted rights-of-way as well as the authority to collect tolls and issue secured bonds. The acts were initiated by proposals from local individuals, cities, or county officials. Parliament then approved these requests and granted improvement rights to non-profit organizations or joint-stock companies.

This paper uses time-series data on acts of Parliament that authorized new construction or improvements to canals and ports in England (see Bogart and Richardson 2006). These series are combined with William Albert's (1972) data on turnpike acts to create the first comparable time-series on road, canal, and port improvement acts in England between 1760 and 1830. The series are also separated into regions, like the southeast, the southwest, the west midlands, the east midlands, and the North. All of the new data are displayed in the appendix so they can be used in future research.

I use the data on the number of road, canal, and port improvement acts to identify whether inter-modal externalities had a substantive impact on road, canal, or port development. Acts measure the number of projects approved by Parliament. My assumption is that groups proposed road, canal, and port acts whenever the net present value of investment was positive. An important component of the net present value calculation is the opportunity cost of investing today (see Pindyck 1991). The 
opportunity cost arises because infrastructure investments are irreversible. In other words, it is not possible to sell an infrastructure project for its full book value and then build it again in the future. The key hypothesis of the paper is that the option value of delaying today and investing in the future diminished when nearby road, canal, and port projects were initiated because there was less uncertainty about the future benefits, which included dividends or higher property values. If so, then some promoters should have initiated their road, canal, or port improvement acts when nearby road, canal, or port improvement acts were also initiated.

The theory of investment under uncertainty also provides guidance as to the timing of the relationship between road, canal, and port acts. It suggests that some promoters should have initiated their project as soon as nearby road, port, and canal improvement acts were passed because there was a higher probability that these projects would be completed in the near future. Promoters may have waited a few extra years if there was still some chance that the project would not be completed, or if they expected that their project would take less time to complete than nearby projects. The theory predicts therefore that more road, canal, port acts should have been passed when a greater number of nearby road, canal, and port acts were passed in the preceding one or two years.

I test these propositions by estimating the relationship between road, canal, and port improvement acts using a vector auto-regression (VAR) model which includes lagged values for real interest rates, the growth of rate industrial production, and indicators for war years. The main finding is that canal acts in year $t$ were positively associated with road acts in t- 1 after controlling for other factors. This same conclusion holds when the VAR model is estimated using first differences or levels of the variables. 
The results show mixed evidence on the inter-modal effects of ports and canals. If the VAR model is estimated in levels, then port and canal acts have no effects on other improvement acts. However, if the VAR model is estimated in first-differences, then changes in road acts in t are positively associated with changes in port acts in t-1 and changes in port acts in t are positively associated with changes in canal acts in t-1. Therefore, there is some evidence that ports contributed to roads and canals contributed to ports, but these findings do not hold in all specifications.

The findings have implications for the literature on British transport development. Canals are often regarded as the most important transportation improvement between 1760 and 1830 (see Ward 1974; Duckham 1983). The results here suggest that road improvements were also important because they complemented canals as well as aiding in the expansion of road transport services. The results also suggest a new interpretation of how road transport improvements were linked with the Industrial Revolution. Some growth models assume that transportation infrastructure is an input in the aggregate production function along with private capital and labor. The standard framework usually assumes that infrastructure exhibits diminishing returns (see Barro and Sala-IMartin 1992), but the results here suggest that during the Industrial Revolution infrastructure exhibited increasing returns. Specifically, there is evidence that the addition of more roads raised the return to further investment in canals. This finding implies that the accumulation of road infrastructure could have substantially increased the aggregate growth rate of the economy. The evidence on the acceleration of growth in the industrial sector between 1760 and 1830 provides some support for this argument (see Crafts and Harley 1992). 
More generally, the results point to the importance of inter-modal network externalities in transport development. The literature has traditionally emphasized intermodal competition rather than inter-modal cooperation. The findings here suggest that policy-makers need to consider the broader benefits of each transport mode and if necessary to coordinate or subsidize projects with significant spillovers.

The paper is organized as follows. The first section provides background on roads, ports, and canals in England. The second section introduces the data. The third section applies the theory of investment under uncertainty to transport network development. The fourth section presents the data analysis. The fifth section concludes.

\section{Background on roads, ports, and canals in England}

The pre-railway transport network in England underwent a substantial transformation between 1760 and 1830 . This section briefly reviews the trends in road, port, and canal improvements, their legal and organization aspects, and reviews the existing hypotheses about which factors influenced transport development.

England had an extensive road network in 1760, but it became larger and better maintained by $1830 .^{3}$ Since the middle ages there was a network of roads connecting London with all major provincial centers, like Bristol, Shrewsbury, York, and Norwich. There were also ‘cross-roads’ connecting provincial centers. After 1760 many primary and secondary roads were resurfaced with gravel and were widened to allow for greater traffic. There was also greater construction of new roads, especially near industrial areas and large cities. New road construction accelerated in the 1790s and early 1800s and continued up to 1830 .

\footnotetext{
${ }^{3}$ For an overview of road improvements see Albert (1972) and Pawson (1977).
} 
As an island nation, Britain had ports since time immemorial. ${ }^{4}$ Over time ports were restricted to a set of locations where customs taxes were collected. In 1760, there were 74 ports in England or Wales and most were located in the southeast near London. The expansion of foreign trade during the mid- $18^{\text {th }}$ century placed greater demands on existing port facilities. New docks and harbors were needed to handle larger ships and the increased volume. Wet docks were constructed in the major ports of Liverpool, Bristol, London, and Hull as well as in emerging ports like Lancaster, Goole, and Grimsby. There were also improvements to harbors in smaller ports throughout the country, many of which served specific types of trade. All of these improvments contributed to a substantial increase in port capacity and efficiency by 1830 .

The canal era began in earnest with the opening of the Duke of Bridgewater's canal in 1761. ${ }^{5}$ It linked the town of Worsley with Manchester. It was enormously successful because it allowed the Duke to sell coal from his estates to a large number of urban consumers and factories. Bridgewater's canal was quickly emulated. Birmingham had its first canal in 1772 and several river systems, like the Trent, Mersey, Severn, and Humber, were linked by canals in 1777 . The initial burst of investment slowed between 1775 and 1789, but was later reignited in the 1790s. The years 1793 and 1794 are famously known as the 'canal mania,' in which 28 canals were initiated, mostly in the midlands and the north. The most famous was the 60-mile Grand Junction canal connecting London with Birmingham. The Grand Junction specialized in long-distance transit, but it was unique in that most canals were designed to transport coal or agricultural goods to nearby urban areas. There was another flurry of canal promotion in

\footnotetext{
${ }^{4}$ For an overview of improvements in ports see Jackson (1983).

${ }^{5}$ For an overview of canal development see Ward (1974) and Duckham (1983).
} 
the early 1810s but it was less substantial than the canal mania. By 1830 the era of new canal construction was largely over, but not before nearly 2000 miles of navigable canals had been completed.

\section{I.1 Legal and Organizational Aspects of Transport Improvements}

Road, port, and canal improvements shared a common feature in that they all required an act of Parliament for their implementation. Common law and statutory law dating from the 1500s dictated that local inhabitants were required to provide for the maintenance of nearby roads, waterways, and ports, but they were not required to improve them. Even if local inhabitants wanted to build a new road, canal, or dock it would have been difficult without first obtaining rights-of-way through an act of Parliament. In the $18^{\text {th }}$ century, acts were very specific in that they gave a group of individuals, a city, or a company the right to improve a particular road, canal, or port. Improvements might include new construction, the diversion or widening of an exiting route, or simply better maintenance. Acts were also crucial because they gave individuals, cities, and companies’ rights to levy tolls and issue bonds secured by the income from the tolls. The tolls and bonds provided the financial sources which paid for most projects. The tolls were particularly important for roads because they allowed local communities to share the fiscal burden with through-travelers (see Levinson, 2002).

Throughout the 1700s and early 1800s Parliament passed thousands of acts dealing with local infrastructure (Innes 1998). Interestingly very few of these acts were initiated by the Ministry or Parliament. Instead local individuals and officials initiated acts with petitions submitted to Parliament. For example, in 1742, the Justices of Peace, 
gentlemen, and other persons living near the road between Harlow and Great Chesterford submitted the following petition stating the need for an act to improve their road:

The aforesaid road about 25 miles in length, is by reason of the deepness of the soil and many heavy carriages passing through it, become very ruinous and in the winter many parts are almost impassable for wagons and carriages, and also for horses laden; and other parts are dangerous to travelers, and the roads cannot by the ordinary course appointed by laws and statutes be effectually amended without the aid of an act of parliament. $^{6}$

The preceding petition resulted in the passage of an act for repairing and widening the road between Harlow and Great Chesterford in the same year of $1742 .^{7}$ Such acts are sometimes referred to as 'turnpike acts,' because they authorized the erection of a gate for collecting tolls. Similar petitions were also introduced by local property-owners, businessmen, and officials stating the need to build wet docks or canals. In this sense, the development of roads, ports, and canals was highly decentralized. Parliament approved projects, but it did not initiate them.

Parliament did influence transport development through its regulations. One of the most important concerned the organizational form of transport authorities. Road acts named several individuals living near the road as trustees and gave them authority to make decisions about improvements, but it forbade trustees from earning direct profits from the tolls. Instead it was expected that trustees would be willing to implement and oversee road improvements for the betterment of their nearby property or business. Many early port authorities were also restricted from earning profits through the tolls, but starting in the early 1800s it was increasingly common for port acts to create joint-stock companies with legal rights to pay dividends to shareholders. Many dock improvements in the major ports, like Bristol, Hull, and London, were undertaken by joint stock

\footnotetext{
${ }^{6}$ This passage came from the Journals of the House of Commons, 8.12.1743.

${ }^{7}$ Ibid. 23.2.1743.
} 
companies as opposed to dock trusts (Jackson 1983, p. 203). For canals, joint stock companies were always the dominant organizational form. Their financial success varied, but dividends were generally high, averaging 5.75 percent (see Duckham 1983, p. 123). The indirect returns from canals were also large, particularly for mining interests and industrialists.

\section{I.2 Factors Influencing Transport Development}

The English transport network developed between 1760 and 1830 due to several factors. At a macro-level, annual fluctuations in investment were related to changes in interest rates, trade, or industrial production. T.S. Ashton (1968) argued that infrastructure projects in the $18^{\text {th }}$ century were sensitive to long-term interest rates because they entailed large up-front investments in materials and structures. Ashton's argument has been criticized in many works, but it remains a key hypothesis in the literature. $^{8}$ Another argument is that higher economic growth in the 1760s, 1790s, and 1810s stimulated transport investment, while the economic slowdown in the 1770s and 1800s deterred investment. ${ }^{9}$ Economic growth was important because it influenced the expected revenues earned by road, port, and canal projects. It also influenced the indirect returns earned by property-owners and businesses.

There is some evidence in the literature that network externalities also affected English transport development. For example, it appears that some communities delayed road improvements until other communities improved contiguous roads, particularly those that provided connections to London (Bogart 2007). There is also some evidence

\footnotetext{
${ }^{8}$ For example, Duckham (1983 p. 103-04) questions the negative correlation between interest rates and canal acts.

${ }^{9}$ Ward (1974, p. 161) argues that the extension of inland navigation was 'an effect of the concurrent growth and commercialization of the English Economy.' Pawson (1977, p. 129) argues that road developments were greatly influenced by economic growth after 1750 .
} 
that communities learned about the benefits of road improvements from neighboring communities (Albert 1972). Of particular importance in this paper is the possibility that externalities existed between modes, like roads, canals, and ports. Baron Duckham (1983, p. 132) argues that ports, like Liverpool, were spurred by the development of canals in their hinterland and even further away. John Armstrong and Philip Bagwell (1983, p. 161) argue that in many ports, coastal ships "fed the river barges and canal boats with traffic and in return were fed by them.” Eric Pawson (1977) argues that developments in road and waterway transport were inter-dependent; noting that many turnpike roads were connected with river ports (p. 164). Lastly, Charles Hadfield provides evidence that the Duke of Bridgewater changed the route of his famous canal so that it would end in Manchester in part because road access was better (1968, p. 29).

The existing literature has noted the inter-connection between road, canal, and port development, but it has not formulated testable hypotheses regarding how road, canal, and port improvements were inter-related. The following section describes data on road, canal, and port improvement acts. The subsequent section uses investment theory to develop testable hypotheses on the inter-relationship between modes.

\section{Data: Road, Canal, and Port Improvement Acts}

The Parliamentary Archives maintains a database with the titles of every act in Britain starting in 1500. Bogart and Richardson (2006) have used the titles to identify every act dealing with specific road, canal, and port improvements between 1760 and 1830. The data are particularly useful because they specify the location and the year when every project was approved by Parliament. 
There were two main types of road, canal, and port acts. The first type created a new statutory authority with rights to improve or construct a road, canal, or port. For example, an act in 1790 created a new authority for "making and maintaining a navigable Canal from Merthyr Tidvile to and through a Place called The Bank, near the Town of Cardiff in the County of Glamorgan.," ${ }^{\prime 0}$ Another act in 1769 created an authority for "repairing, improving and better preserving of the Harbour and Quay of Wells, in the County of Norfolk."11 Another act in 1787 was "for amending, widening and keeping in Repair the Road leading from the Town of Nottingham to the Town of Mansfield, in the County of Nottingham.,"12

The second type of statutory authority act amended rights granted in a previous act. Most renewed or enlarged the powers of existing authorities, but did not propose additional improvements. Some amendment acts, however, included new projects that were to be undertaken by the same statutory authority. For example, an act in 1824 was passed "to abridge, vary, extend and improve the Bristol and Taunton Canal Navigation, and to alter the Powers of an Act of the Fifty-first Year of His late Majesty for making the said Canal.”13 In this particular case, the rights of the Bristol and Taunton canal company were amended, in part so that they could improve and extend the canal.

In order to analyze the inter-connection between road, canal, and port development it is necessary to separate all acts that authorized improvements from acts that simply amended rights. For roads, I use William Albert's (1972) series of acts that initiated turnpike authorities on roads not previously under their control. Albert's series has been

\footnotetext{
${ }^{10}$ The titles come from a database in the Parliamentary archives. See HL/PO/PU/1/1790/30G3n118

${ }^{11}$ Ibid. HL/PO/PU/1/1769/9G3n9

${ }^{12} \mathrm{Ibid} . \mathrm{HL} / \mathrm{PO} / \mathrm{PU} / 1 / 1787 / 27 \mathrm{G} 3 n 32$

${ }^{13}$ Ibid. HL/PO/PB/1/1824/5G4n221
} 
used by many economic historians and is generally regarded as a close approximation for all road acts that authorized new improvements. Albert's series does not include road acts in Wales, Scotland, or Ireland and so the analysis is restricted to England alone.

Following Bogart and Richardson (2006), I use the Parliamentary Archives data to create a similar series by combining all acts for making canals with amendment acts that authorized extensions, branches, or variations of the canal route. I also combine all acts that authorized construction, repairs, or extensions to quays, docks, piers or any other work related to port improvements. Together the data consist of an annual time-series on all road, canal, and port improvement acts in England between 1760 and 1830.

Figure 1 shows the number of road, port, and canal improvement acts in England in each year from 1760 to 1830 . Road improvement acts were very high in the 1760 s, 1790s, and 1820s. The canal mania of the 1790s had the greatest number of canal acts, but it was not the only period of improvement, as many canal acts were passed in both the 1760s and early 1810s. Port improvement acts were less common, which is to be expected given the limited number of suitable coastal sites. Also there was no equivalent to the canal mania, in which a cluster of port improvements were initiated in a few years.

Road, canal, and port improvement acts are also separated into the north, west midlands, east midlands, southeast, and the southwest of England based on the locations described in the act. ${ }^{14}$ In many cases, canal and road improvements spanned multiple counties and so I chose to analyze regions rather than counties. Moreover, the region is a

\footnotetext{
${ }^{14}$ The North included Cumberland, Northumberland, Westmoreland, York, Lancaster, and Chester. The West Midlands included Shropshire, Staffordshire, Derbyshire, Nottinghamshire, Leicester, Northampton, Buckinghamshire, Bedfordshire, Hertfordshire, Warwick, Worcester, Hereford, Oxford, and Monmouth. The east Midlands include Lincolnshire, Norfold, Suffolk, Cambridgeshire, and Huntingdon. The southeast includes Essex, Kent, Middlesex, Surrey, and Sussex. The Southwest includes Hampshire, Berkshire, Gloucestershire, Wiltshire, Dorsetshire, Somersetshire, Devonshire, and Cornwall.
} 
useful unit of analysis because some transport improvements affected projects in neighboring counties, but not in neighboring regions.

Other economic and political variables are also incorporated into the analysis. Interest rates are measured using the real yield on long-term government bonds, known as consols. Bond yields come from the Global Financial Database and are available on an annual basis from 1700 to $1830 .^{15}$ For the inflation rate, I use a three-year moving average of the percentage change in Greg Clark’s (2001) consumer price index. As yet there is no widely-accepted time-series on annual British G.D.P. growth between 1760 and 1830. Instead, I use Crafts and Harley’s (1992) estimates of the annual growth rate for industrial production. Manufacturing was the most dynamic sector in the British economy and thus the growth rate of industrial production represents a key component of G.D.P. growth. Warfare is another factor that affected the benefits of roads, ports, and canals by changing domestic and international trade patterns. The general histories by Holmes and Szechi (1993) and Evans (2001) provide all years when Britain was at war.

\section{III.Inter-modal network externalities and Transport Investment: Theory}

Economists have traditionally modeled investment decisions using net present value (NPV) calculations. According to the NPV-rule firms will invest whenever the expected present value of all future benefits exceeds the present value of investment and maintenance costs. Several economists have pointed out that the standard NPV-rule omits the option value of waiting to decide whether to invest in the future (see Pindyck, 1991). The option value can be significant if investments are irreversible and there are uncertainties about the benefits or costs of investing. Once these uncertainties are

\footnotetext{
${ }^{15}$ For details on the Global Financial Database see http://www.globalfinancialdata.com/.
} 
resolved, the option value of waiting diminishes and investments are either undertaken or they are dropped.

This theoretical framework can be applied to network externalities between road, canal, and port investments. For example, if the improvement of nearby roads and ports makes it easier to bring goods to and from a canal, then the option value of waiting to decide whether to invest in a canal tomorrow diminishes when road and port projects are completed today because there is less uncertainty about the future benefits of the canal. Consider the following numeral example which is based on Pindyck (1991). Suppose there is a canal project that costs $£ 800$ to complete and that the risk-free interest rate is $10 \%$. Suppose further that if the canal is constructed in year zero it will yield a benefit of $£ 50$ in year zero and the same for all subsequent years unless nearby road and port projects are completed, in which case the canal will yield a benefit of $£ 150$. Lastly, assume that canal promoters are uncertain in year zero whether road and port projects will be completed, but this will be revealed in year one. For the moment, suppose that promoters believe there is a 50 percent probability that road and port projects will be completed.

If investing in year zero was the only option, then canal promoters would go ahead with their project because the expected net present value of the canal is $£ 250 .{ }^{16}$ However, it would be better to wait until year one and find out whether nearby road and port projects are completed. The NPV of waiting to decide to invest in year one is $£ 386$,

\footnotetext{
16 The net present value of investing in year zero is

$-800+50+0.5 \times\left(\sum_{t=1}^{\infty} 150 /(1.1)^{t}\right)+0.5 \times\left(\sum_{t=1}^{\infty} 50 /(1.1)^{t}\right)=-750+750+250=250$.
} 
which is greater than the NPV of investing in year zero. ${ }^{17}$ The option value is higher because canal promoters will only initiate the project in year one if nearby road and port projects are completed.

The preceding example illustrates the main hypothesis that more road, canal, or port projects should have been initiated once it was known that nearby road, canal, and port projects would be completed in the future. ${ }^{18}$ More specific hypotheses can be developed by adding several features to the model. First, there was a time-lag between the act of parliament that initiated transport projects and their date of completion. The earlier example can be modified to show that canal promoters will initiate their project once they learn that road and port acts have been passed and not when these projects are completed. ${ }^{19}$ The reason is that much of the uncertainty about the future benefits of the canal would have been resolved once road and port acts were passed. However, if there was some probability that projects would not be completed even when an authorizing act was passed, then promoters might delay their project until after they learned more about the likelihood or degree of completion. The implication is that acts authorizing road, canal, or port improvements may not have been passed until one or two years after acts for nearby road, canal, and port projects were passed.

\footnotetext{
${ }^{17}$ The net present value of waiting until year one is $0.5 \times\left[-800 /(1.1)+\sum_{t=1}^{\infty} 150 /(1.1)^{t}\right]=386$.

${ }^{18}$ Road, canal, and port promoters may have also delayed their projects until they knew whether manufacturing production increased or interest rates declined. I have omitted discussion of these factors, but they are incorporated in the empirical analysis.

${ }^{19}$ Assume that all projects take one year to complete. The NPV of initiating in year 0 is still below the NPV of waiting until year one when it is known whether nearby road and port acts have been passed. In year one, the NPV of investing is higher than the NPV of waiting to invest in year two since$$
-800+\sum_{t=1}^{\infty} 150 /(1.1)^{t}>-800 /(1.1)+\sum_{t=2}^{\infty} 150 /(1.1)^{t} \text {. }
$$ 
Second, the timing of investment may be different across the modes because of differences in construction times. Typically road and port projects took three to four years to complete following their act, while canal projects usually took five years or more. ${ }^{20}$ If the earlier example is adapted so that the canal takes one year longer to complete than nearby road and port projects, the NPV calculations suggest that the canal promoter will initiate as soon as they learn that road and port acts have been passed. The reason is that promoters lose revenues if they are constructing their canal long after nearby roads and ports have been completed. ${ }^{21}$ Now consider the decision to initiate road and port projects given uncertainty about the completion of canals. Here the NPV calculations suggest that promoters will delay their road or port projects by one year after they learn whether canals will be initiated. ${ }^{22}$ The reason is that the benefits of road and port projects are too small unless the canal project has been completed, and therefore, it is better to wait an extra year so that all projects open at the same time. These particular examples

\footnotetext{
${ }^{20}$ Jim Shead provides detailed information on canal construction times. See 'History by Waterway.' For more details on the length of road improvements see Pawson (1977). Details on port construction times are scattered throughout the literature. The River Humber organization reports that the port improvements in Hull were begun 1775 and completed in 1778. See http://website.lineone.net/ ktaylor297/index12.htm.

${ }^{21}$ In this case, there is a possibility that the canal promoter will initiate in year zero if there is sufficiently high probability that road or harbor projects will be initiated. Suppose $\mathrm{q}$ is the probability that road or harbor projects are initiated in year one, then the NPV of initiating in year zero is$$
-800+q \times \sum_{t=2}^{\infty} 150 /(1.1)^{t}+(1-q) \times \sum_{t=2}^{\infty} 50 /(1.1)^{t} .
$$

The NPV of waiting to decide until year one is $q \times\left[-800 /(1.1)+\sum_{t=3}^{\infty} 150 /(1.1)^{t}\right]$.

Manipulation of these two expressions shows that the NPV of initiating in year zero is higher if $q>0.88$.

${ }^{22}$ Suppose the road or port promoter knows in year one that the canal will be completed in year three. The NPV of initiating in year one when the road/port project takes 1 year and canal projects take 2 years is

$-800+50 / 1.1+\sum_{t=3}^{\infty} 150 /(1.1)^{t}=609$.
}

The NPV of waiting to initiate the road/port improvement in year 2 is

$-800 /(1.1)+\sum_{t=2}^{\infty} 150 /(1.1)^{t}=636$. 
suggest that canal projects should have been initiated more quickly following the passage of acts authorizing road and port projects, whereas road and port projects should have been initiated more slowly after the passage of canal acts.

A final set of considerations deals with differences in how network externalities affected the benefits of roads, canals, and ports. The first deals with the definition of 'nearby projects.' Roads likely had a greater effect on canals and ports within their region because they were shorter in distance, whereas port improvements should have the widest impact of all three modes because the coastal trade was national in scope. The second addresses the fact that construction costs were much higher for canals than road or port improvements. ${ }^{23}$ One can show in the original example, that the incentive to wait until year one to decide whether to invest increases with the investment cost. ${ }^{24}$

Therefore, canal promoters should have had a greater incentive to wait until nearby road and port projects were initiated. A third consideration deals with differences in the motives of promoters across the modes. As discussed earlier, roads were promoted by non-profit trusts, who were interested in increasing their property values or business profits, whereas canals were promoted by joint-stock companies, who were interested in the direct profits from the canal. The different motives could have influenced whether inter-modal network externalities had a greater impact in one mode versus another. One possibility is that the profits earned by joint-stock canal companies were more affected by

\footnotetext{
${ }^{23}$ Ward (1974) shows that construction costs for canals often exceeded $£ 100,000$. This was substantially lower than roads (see Pawson 1977) and port improvements (see Chalklin 1998, p. 14), which ranged between $£ 10,000$ and $£ 20,000$.

${ }^{24}$ Let I be the investment costs. Using the same parameters as in footnote 16, the NPV of investing in year zero is $-I+1050$. The NPV of waiting until year one is $0.5 \times(-I / 1.1)+750$. Manipulating these expressions shows that the NPV of waiting until year one is greater than the NPV of investing in year zero only if the investment cost exceeds 550 .
} 
the completion of nearby road projects because toll revenues changed immediately. By contrast, property values and business profits for road trustees would have changed more slowly because of the costs of renegotiating with tenants or customers.

\section{Empirical Analysis of Inter-modal Network Externalities}

In this section, I analyze whether inter-modal network externalities influenced the development of roads, canals, and ports in England. It is useful to begin by examining the correlations between road, canal, and port acts and their lagged values using the national data. In table 1 , all inter-modal correlation coefficients above 0.10 are bolded. The data show that road acts are positively correlated with ports in $t-1$, but negatively correlated with ports t-2 and t-4. Road acts are also negatively correlated with canals in t-3 and t-4. Canal acts are positively correlated with roads in t-1 and positively correlated with ports in t-1 and t-2. Port acts have no substantial inter-modal correlations.

Table 2 reports the correlations between road, canal, and port acts within the southeast, southwest, east midlands, west midlands, and northern regions. The data show a relatively large positive correlation between canal acts in $t$ and road acts in $t-1$, but no relationship between canal acts and port acts or between road and port acts.

Vector auto-regression (VAR) analysis provides a more rigorous tool to analyze the importance of inter-modal network externalities. Before specifying the VAR model, it is necessary to determine whether the time-series variables are stationary. Table 3 reports augmented Dickey-Fuller tests for road, port, and canal improvement acts as well as the growth rate of industrial production, real interest rates, and a dummy variable for war years. The tests show that all the variables are stationary. This suggests that it is not 
inappropriate to examine the variables in levels. Later I discuss how the results are different when the variables are analyzed in differences.

The VAR model builds on the theory discussed earlier and specifies an interrelationship between road, port, and canal acts after controlling for the growth of industrial production, real interest rates, and war years. The following equation specifies the model.

$$
X_{t}=\sum_{k=1}^{K} \beta_{k} X_{t-k}+\sum_{k=1}^{K} \gamma_{k} Z_{t-k}+\varepsilon_{t}
$$

$X_{t}$ is a vector that includes road, port, and canal acts in year t; $Z_{t}$ is a vector that includes the growth rate of industrial production, real interest rates, and a dummy for war in year $\mathrm{t} ; \varepsilon_{t}$ is an error term; $K$ describes the number of time-lags. The model contains three equations corresponding to the three vectors in $X_{t}$. Each individual equation allows the number of improvement acts in year $\mathrm{t}$ to be determined by its lagged values, the lagged values of other improvement acts, and lagged values for the economic environment. The key variables in each equation are the number of improvement acts for other modes in the year $t-1, t-2, \ldots, t-K$. If there were inter-modal network externalities, say from roads and ports to canals, then the estimation should show that higher road or port acts in some year $t-k$ increases canal acts in $t$. The model places no restrictions on which improvement acts influence the others and allows the data to reveal such relationships.

The variables for the growth of industrial production, real interest rates, and warfare are assumed to be sequentially exogenous in the model. In the case of industrial production, the argument is that a higher growth rate in $t-1, t-2, \ldots, t-K$ will influence 
improvement acts, but improvement acts will not influence industrial production until at least $K$ periods. As long as $K$ is less than five years, then this argument is reasonable because road and port improvements often took three to four years to complete, and canals around five. Therefore, a significant feedback effect of improvement acts on industrial production is likely to take at least five years. ${ }^{25}$

Theory suggests that promoters will initiate their projects shortly after nearby projects have been authorized by their acts of Parliament. This would suggest that the lag length $K$ should be less than four years. The optimal lag order can also be determined using statistical tests. The Akaike's Information Criterion test implies that the optimal lag is two years, while the Schwarz's Bayesian Information Criterion and Hannan and Quinn Information Criterion tests imply that the optimal lag is one year. Below I report the results using a one-year lag to keep the model parsimonious. The results are generally similar when two-year lags are used.

Table 4 reports the VAR estimates using the national time series. The findings suggest that inter-modal network externalities had a relatively weak influence on transport development at the national level. The results in column 1 show that road and port improvement acts in t-1 are positively associated with canal acts in $\mathrm{t}$ after controlling for other factors, but nether is statistically significant. In column 2, port improvement acts in t-1 are positively associated with road improvement acts in $\mathrm{t}$ and in column 3 canal acts in t-1 are positively associated with port improvement acts in t, but none of these coefficients is significant.

\footnotetext{
${ }^{25}$ There could be a short-term feedback from improvements to industrial production via aggregate demand effects but these are likely to be small and should not dramatically affect the estimates. There might also be a correlation between industrial production in $t-k$ and the error term in some future year like $t+j$. In models where variables are sequentially exogenous, the bias is usually lower if $\mathrm{T}$ is large (Wooldridge 2002, p. 302), which is the case here with $\mathrm{T}=69$.
} 
The VAR estimates in table 4 also show that industrial production, real interest rates, and warfare had a substantial impact on transport development. There is a positive and significant relationship between a higher growth rate of industrial production in t-1 and both road and port improvement acts in t. This finding is significant because it suggests that economic growth raised the benefits of improving transportation. There is also a negative and significant relationship between real interest rates in t-1 and road improvement acts in t. This suggests that at least one transport mode was sensitive to long-term interest rates, as hypothesized by Ashton. Lastly, there is a negative and significant relationship between war in $\mathrm{t}-1$ and port improvement acts in t. This finding suggests that warfare lowered the benefits of improving ports by disrupting international trade.

In the national data, the identification of inter-modal network externalities might be obscured by the distance between road, port, and canal projects. The theory suggests that promoters will be influenced by the initiation of nearby projects, but the definition of nearby projects could vary across the modes. It might be that port projects influence promoters throughout the country, while road and canal projects influence promoters in their region only. These possibilities can be explored using the regional series on road, port, and canal improvement acts.

Table 5 reports estimates from a VAR model which pools the data from four of the five regions. The west midlands region is dropped in this specification because it is landlocked. The results show there is evidence that road improvements influenced canal development at the regional level. In column 1 , canal acts in $t$ are positively associated with road acts in t-1 after controlling for the other factors. However, there is still no 
evidence that port improvements influenced roads and canals, or that canals influenced roads and ports.

Table 6 reports estimates from a pooled regional VAR analysis that drops port improvement acts and adds the west midlands region. The conclusions are the same as table 5. They show a positive and significant relationship between canals acts in $t$ and road acts in t-1. Overall, the results from the regional and national data show that roads affected canal projects in their region, but not in the country as a whole. This makes sense given that improved roads were between 10 and 20 miles in length and thus they were likely to influence decisions regarding canal projects within 50 or 100 miles which is the approximate length or width of most regions.

The preceding analysis focused on the relationship between road, canal, and port acts in levels. The variables can also be analyzed in first differences. In this case, the VAR estimates identify whether an increase (or decrease) in road acts from year t-2 to t-1 resulted in an increase (or decrease) in canal acts from t- 1 to t. Table 7 shows the estimates of the VAR model using differences of the national data and table 8 shows the estimates using differences of the regional data. Both the national and regional data show that the difference in canals acts in $\mathrm{t}$ is positively correlated with the difference in road acts in t-1 after controlling for other factors. This is similar to the earlier finding that the level of canal acts in $\mathrm{t}$ is positively correlated with the level of road acts in t-1.

The results are somewhat different for port and canal acts. The national and regional data show that the difference in road acts in $\mathrm{t}$ is positively correlated with the difference in port acts in $\mathrm{t}-1$, while the national data show that the difference in ports acts in $\mathrm{t}$ is positively correlated with the difference in canal acts in t-1. Thus there is some evidence 
that port development contributed to road development and canal development contributed to port development, but these results hold only in some specifications.

The results can be interpreted using the model of investment under uncertainty. The most robust conclusion is that the option value of waiting to invest in a canal diminished when nearby road projects were initiated because there was less uncertainty about the future benefits. Canals typically took longer to complete than roads, and therefore canal promoters would have lost more revenues if they did not initiate their project as soon as nearby road projects were authorized by Parliament. Furthermore construction costs were higher for canals than roads or ports, and therefore the value of waiting until nearby road and port projects were initiated should have been higher for canal promoters. Building a canal without adequate road connections could be a very costly mistake for promoters.

The results are also consistent with the argument that organizational differences made canal promoters more reactive to the initiation of road projects. Roads were improved by non-profit trusts whose main goal was to increase local property values or business profits. It is possible that these indirect benefits changed more slowly in response to the completion of nearby canals or harbors because of the transaction costs of renegotiating rents with tenants or renegotiating prices with customers. Canals, on the other hand, were promoted by joint stock companies whose main objective was to maximize profits from the tolls. It is likely that the toll revenues changed more quickly when nearby road and port projects were completed because traffic on the canal increased. The direct profit-motive thus strengthened inter-modal externalities. 


\section{Conclusion}

Transport networks include several infrastructure modes. Each mode can operate independently, but only to a limited extent because of the need for trans-shipment. Goods entering ports rarely stay near the docks, and instead they are shipped by rail, road, or inland waterway to distant markets or factories. Some goods, like agricultural products, are shipped by road from dispersed locations before being transported by rail or water over greater distances. Different modes also complement one another by relieving congestion. Without adequate roads or airports, passengers and high-value goods must be shipped by rail or water, thus adding to congestion on these modes. Likewise without rail and waterways, freight and low-value goods will add to congestion on roads and in the air.

Although it is clear that different modes are complementary, it is not obvious that inter-modal externalities significantly affect the development of transport networks. For example, it is not clear that private or public authorities would build or improve fewer roads if ports and other waterways were under-developed. The potential for inefficient investment is likely to be greater when decision-making is decentralized, because individuals or local organizations do not take spillovers into account when they choose to undertake a project.

This paper uses history to address whether inter-modal network externalities had a significant effect on the development of roads, canals, and ports in England from 1760 to 1830. Over this 70-year period, Britain made substantial investments in its transport network, making it one of the most extensive in the world. Using a VAR model with time-series data on road, port, and canal improvement acts, I show that canal acts in year 
$\mathrm{t}$ were associated with higher road acts in $\mathrm{t}-1$ after controlling for other factors. This finding does not necessary imply that inter-modal externalities existed, but they do strongly suggest that the option value of waiting to invest in canals diminished when nearby roads were initiated. Future research should further examine the inter-connection between roads, ports, and canals through case-study analysis or through additional econometric analysis. $^{26}$

The findings have implications for the literature on the development of the British transport network during the Industrial Revolution period. Canals are often viewed as the most important transport improvement of this era, and there are also suggestions that canals spurred the development of other transport modes. The results here suggest that canals did not have spillover effects on roads and instead canals were partly driven by roads. The results also suggest that the accumulation of road infrastructure might have contributed to a significant increase in aggregate economic growth by providing greater road transport services and increasing the returns to canal projects.

The results also have broader policy implications because they suggest that intermodal network externalities can influence the development of transport networks, particularly under a decentralized system of decision-making. It is not clear whether there were long delays in canal improvements because road authorities did not internalize the spillovers from their investment, but there was a clear potential for inefficiency. Policy-makers need to consider the broader benefits of each transport mode and if necessary to coordinate or subsidize projects with significant spillovers.

\footnotetext{
${ }^{26}$ For example, future research could address measurement error and omitted variables problems with twostage least squares (see Wooldridge 2002). However, it is difficult to find an instrumental variable that is correlated with road acts in t-1, but uncorrelated with the error term for canal acts in t. Political variables, like years when there were elections or new prime ministers could potentially work, but it is not clear why they would affect road acts but not canal acts
} 


\section{Appendix}

Tables 9 and 10 and list all port and canal improvement acts in England between 1760 and 1830. 


\section{References}

Albert, William (1972). The Turnpike Road System in England, 1663-1840. Cambridge University Press, Cambridge.

Ashton, T. S. (1968). The Industrial Revolution, 1760-1830. Oxford University Press, Oxford.

Armstrong, John and Philip Bagwell (1983). Coastal Shipping. In: Aldcroft, Derek and Michael Freeman (ed) Transport in the Industrial Revolution. Manchester University Press, Manchester.

Banister, David and Joseph Berechman (2000). Transport Investment and Economic Development. UCL Press, London.

Barro, Robert J. and Xavier Sala-I-Martin (1992). Public Finance in Models of Economic Growth. The Review of Economic Studies 59: 645-661.

Bogart, Dan (2007). Neighbors, Networks, and the Development of Transport Systems: Explaining the Diffusion of Turnpike Trusts in Eighteenth-Century England. Journal of Urban Economics 61: 238-262.

Bogart, Dan and Gary Richardson (2006). Parliament, Property Rights, and Public Goods in England from 1600-1815. Working Paper.

Chalklin, Christopher (1998). English Counties and Public Building, 1650-1830. Hambledon, London.

Clark, Greg (2001). Farm Wages and Living Standards in the Industrial Revolution: England, 1670-1869. Economic History Review 3: 477-505. 
Crafts, Nicholas, and C. Knick Harley (1992). Output Growth and the British Industrial Revolution: A Restatement of the Crafts-Harley View. The Economic History Review 45: 703-730.

Duckham, Baron F. (1983). Canals and River Navigations. In: Aldcroft, Derek and Michael Freeman (ed) Transport in the Industrial Revolution. Manchester University Press, Manchester.

Evans, Eric J. (2001). The Forging of the Modern State: Early Industrial Britain 1783 1870. Longman, London.

Global Financial Data (2007). United Kingdom 2 1/2\% Consol Yield. Available via http://www.globalfinancialdata.com/index.php3?action=detailedinfo\&id=1301.

Great Britain. Parliament. House of Commons (1803). Journals of the House of Commons. HM Stationary, London.

Hadfield, Charles (1968). The Canal Age. Praeger, New York.

Holmes, Geoffrey and Daniel Szechi (1993). The Age of Oligarchy: Pre-IndustrialBritain 1722-1783. Longman, London.

Innes, Joanna (1998). The Local Acts of a National Parliament: Parliament’s Role in Sanctioning Local Action in Eighteenth-Century Britain. In: David Dean and Clyve Jones (ed) Parliament and Locality,1660-1939. Edinburgh University Press, London.

Jackson, Gordon (1983). The Ports. In: Aldcroft, Derek and Michael Freeman (ed)

Transport in the Industrial Revolution. Manchester University Press, Manchester. Levinson, David (2002). Financing Transportation Networks. Edward Elgar, Cheltenham. 
Parliamentary Archives (2007). Portcullis. Available via http://www.portcullis.parliament.uk/DserveA/

Pawson, Eric (1977). Transport and Economy: The Turnpike Roads of Eighteenth Century Britain. Academic Press, New York.

Pindyck, Robert (1991). Irreversibility, Uncertainty, and Investment. Journal of Economic Literature 29: 1110-1148.

Shead, Jim (2007). History by Waterway. Available via http://www.jimshead.com/waterways

Ward, J.R. (1974). The Finance of Canal Building in Eighteenth Century England.Oxford University Press, Oxford.

Wooldridge, Jeffrey (2002). Econometric Analysis of Cross Section and Panel Data, M.I.T. Press, Cambridge MA. 
Tables

Table 1: Road, Port, and Canal improvement acts in England, 1760-1830: Correlations for National Data

(1)

Road in $\mathrm{t}$

Road in $\mathrm{t}-1$

Road in $\mathrm{t}-2$

Road in t-3

Road in $\mathrm{t}-4$

Port in $\mathrm{t}-1$

Port in $\mathrm{t}-2$

Port in t-3

Port in $\mathrm{t}-4$

Canal in t-1

Canal in $\mathrm{t}-2$

Canal in $\mathrm{t}-3$

Canal in t-4

Sources: see text.

0.11

$-0.14$

$-0.07$

$-0.16$

0.01

$-0.10$

$-0.17$

$-0.18$
(2)

Canal in $\mathrm{t}$

$\begin{array}{lcc}0.59 & -0.02 & \mathbf{0 . 1 9} \\ 0.36 & -0.01 & 0.02 \\ 0.22 & -0.07 & -0.06 \\ 0.19 & -0.04 & -0.04\end{array}$

0.00

0.24

0.04

0.03

0.22

0.14

$-0.10$

$-0.01$

0.06

0.00

0.69

0.48

0.30

$-0.05 \quad 0.14$ 
Table 2: Road, Port, and Canal improvement acts in England, 1760-1830: Correlations in Regional Data

Road in $\mathrm{t}$

Road in $\mathrm{t}-1$

Road in $\mathrm{t}-2$

Road in $\mathrm{t}-3$

Road in $\mathrm{t}-4$

Port in $\mathrm{t}-1$

Port in $\mathrm{t}-2$

Port in $\mathrm{t}-3$

Port in $\mathrm{t}-4$

Canal in $\mathrm{t}-1$

Canal in $\mathrm{t}-2$

Canal in $\mathrm{t}-3$

Canal in t-4

Sources: see text.

Notes: The West Midlands Region is dropped because it has no ports.
(1)

Canal in $\mathrm{t}$

$\begin{array}{ccc}0.45 & 0.03 & \mathbf{0 . 2 5} \\ 0.20 & 0.03 & 0.03 \\ 0.17 & -0.01 & -0.02 \\ 0.12 & -0.05 & 0.02\end{array}$

0.09

$-0.04$

$-0.04$

$-0.05$

0.04

0.05

0.10

0.06

0.06

0.07

0.02

0.01

0.06

$-0.01$

$-0.00$

0.05

0.02

$-0.01$

0.47

0.24

0.12

0.07

25

0.02

0.00

$-0.02$

0.07




\begin{tabular}{lc}
\hline \hline Variable & $\begin{array}{c}\text { Test Statistic } \\
\text { (standard error) }\end{array}$ \\
\hline Canal & $-3.515 * * *$ \\
Road & $-4.206 * * *$ \\
Harbor & $-8.158 * * *$ \\
Growth Rate of Industrial Production & $-10.491 * * *$ \\
Real Interest Rates & $-4.370 * * *$ \\
War Dummy & $-2.787 *$ \\
\hline $\begin{array}{l}\text { Notes: *** indicates statistical significance at the 1\% level. * indicates statistical significance at } \\
90 \% .\end{array}$
\end{tabular}


Table 4: Vector Auto-regressions: National Time Series in Levels with 1-year Lag

\begin{tabular}{lccc}
\hline \hline & $\begin{array}{c}(1) \\
\text { Canal in } t\end{array}$ & $\begin{array}{c}(2) \\
\text { Road in } t\end{array}$ & $\begin{array}{c}(3) \\
\text { Port in } \mathrm{t}\end{array}$ \\
Variable & Coeff (stand err) & Coeff (stand err) & Coeff (stand err) \\
\hline Road in t-1 & $0.01(0.04)$ & $0.55(0.10)^{*}$ & $-0.01(0.02)$ \\
Port in t-1 & $0.23(0.23)$ & $0.48(0.57)$ & $-0.07(0.12)$ \\
Canal in t-1 & $0.70(0.09)^{*}$ & $-0.16(0.22)$ & $0.06(0.05)$ \\
Real Yield on Government Bonds in t-1 & $-0.08(0.05)$ & $-0.21(0.12)^{*}$ & $0.00(0.02)$ \\
Growth rate of industrial production in t-1 & $0.07(0.06)$ & $0.31(0.14)^{*}$ & $0.06(0.03)^{*}$ \\
War Dummy in t-1 & $-0.82(0.52)$ & $-0.92(1.31)$ & $-0.48(0.27)^{*}$ \\
Constant & $0.91(0.63)$ & $3.97(1.60)^{*}$ & $0.87(0.31)^{*}$ \\
N & 69 & 69 & 69 \\
R-square & 0.54 & 0.43 & 0.10
\end{tabular}

Notes: * indicates statistical significance at $90 \%$ or above. 
Table 5: Vector Auto-regressions: Regional Time Series in Levels with 1-year Lag

\begin{tabular}{lccc}
\hline & $\begin{array}{c}(1) \\
\text { Canal in } t\end{array}$ & $\begin{array}{c}(2) \\
\text { Road in t }\end{array}$ & $\begin{array}{c}(3) \\
\text { Port in t }\end{array}$ \\
Variable & Coeff (stand err) & Coeff (stand err) & Coeff (stand err) \\
\hline Road in t-1 & $0.06(0.02)^{*}$ & $0.44(0.05)^{*}$ & $0.00(0.02)$ \\
Port in t-1 & $-0.01(0.08)$ & $0.16(0.20)$ & $-0.52(0.05)^{*}$ \\
Canal in t-1 & $0.44(0.05)^{*}$ & $-0.03(0.13)$ & $0.03(0.06)$ \\
Real Yield on Government Bonds in t-1 & $-0.02(0.01)^{*}$ & $-0.05(0.02)^{*}$ & $0.00(0.01)$ \\
Growth rate of industrial production in t-1 & $0.02(0.01)^{*}$ & $0.08(0.02)^{*}$ & $0.01(0.00)^{*}$ \\
War Dummy in t-1 & $-0.01(0.08)$ & $-0.25(0.20)$ & $-0.10(0.06)^{*}$ \\
Constant & $0.13(0.08)$ & $0.84(0.19)^{*}$ & $0.19(0.06)^{*}$ \\
N & 276 & 276 & 276 \\
R-square & 0.26 & 0.27 & 0.03
\end{tabular}

Notes: * indicates statistical significance at $90 \%$ or above. The West Midlands Region is dropped. 


\begin{tabular}{lcc}
\hline \hline & $\begin{array}{c}(1) \\
\text { Canal in } t \\
\text { Variable }\end{array}$ & $\begin{array}{c}(2) \\
\text { Road in t }\end{array}$ \\
Coeff (stand err) & $0.05(0.02)^{*}$ & $0.43(0.05)^{*}$ \\
Road in t-1 & $0.50(0.05)^{*}$ & $0.02(0.10)$ \\
Canal in t-1 & $-0.014(0.008)^{*}$ & $-0.05(0.02)^{*}$ \\
Real Yield on Government Bonds in t-1 & $0.01(0.01)$ & $0.07(0.02)^{*}$ \\
Growth rate of industrial production in t-1 & $-0.10(0.09)$ & $-0.30(0.20)$ \\
War Dummy in t-1 & $0.21(0.08)$ & $1.03(0.19)$ \\
Constant & 345 & 345 \\
N & 0.29 & 0.26 \\
R-square & &
\end{tabular}

Notes: * indicates statistical significance at $90 \%$ or above. The West Midlands Region is included. 
Table 7: Vector Auto-Regressions: National Time Series in Differences with 1-year Lag

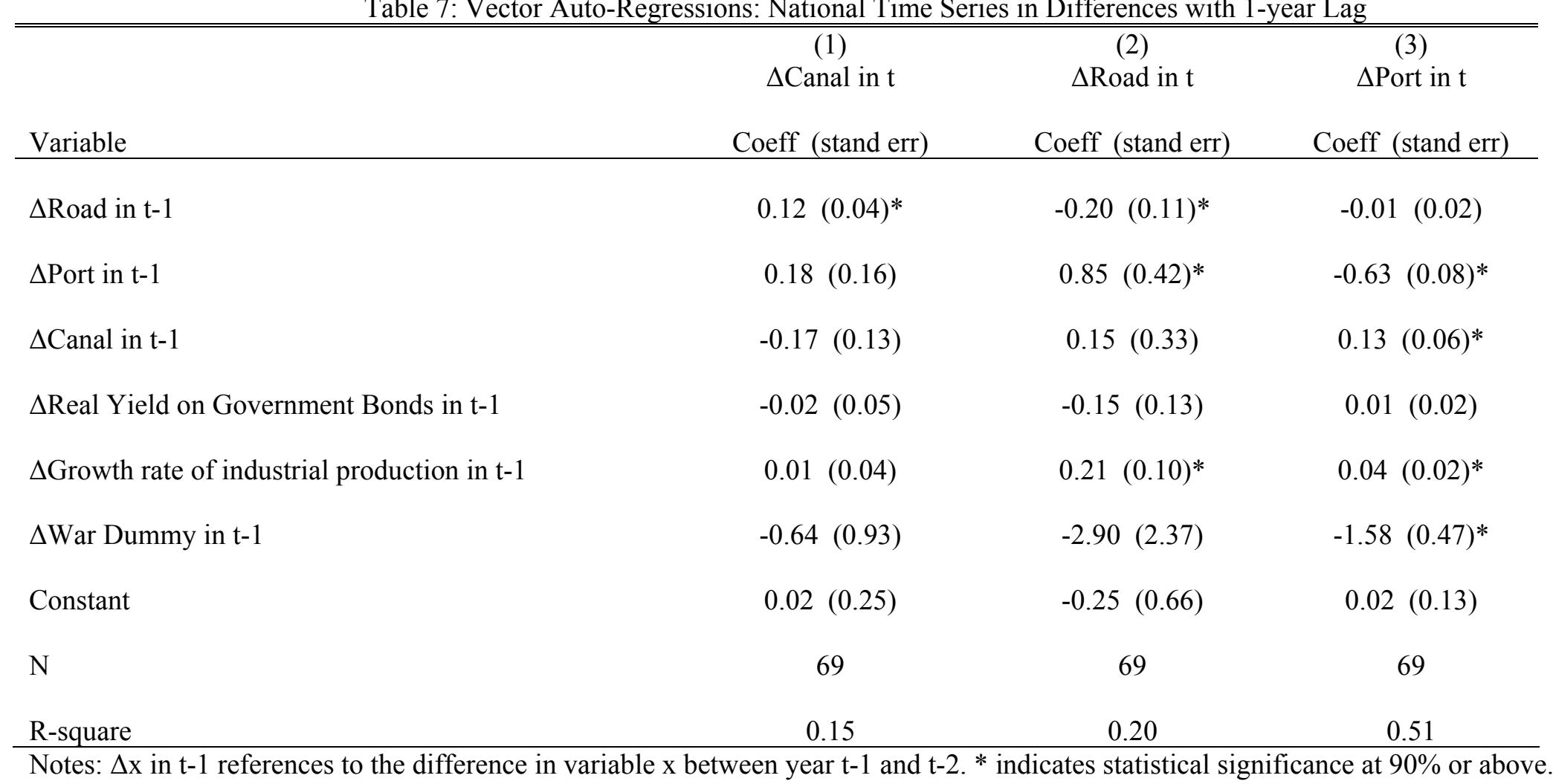




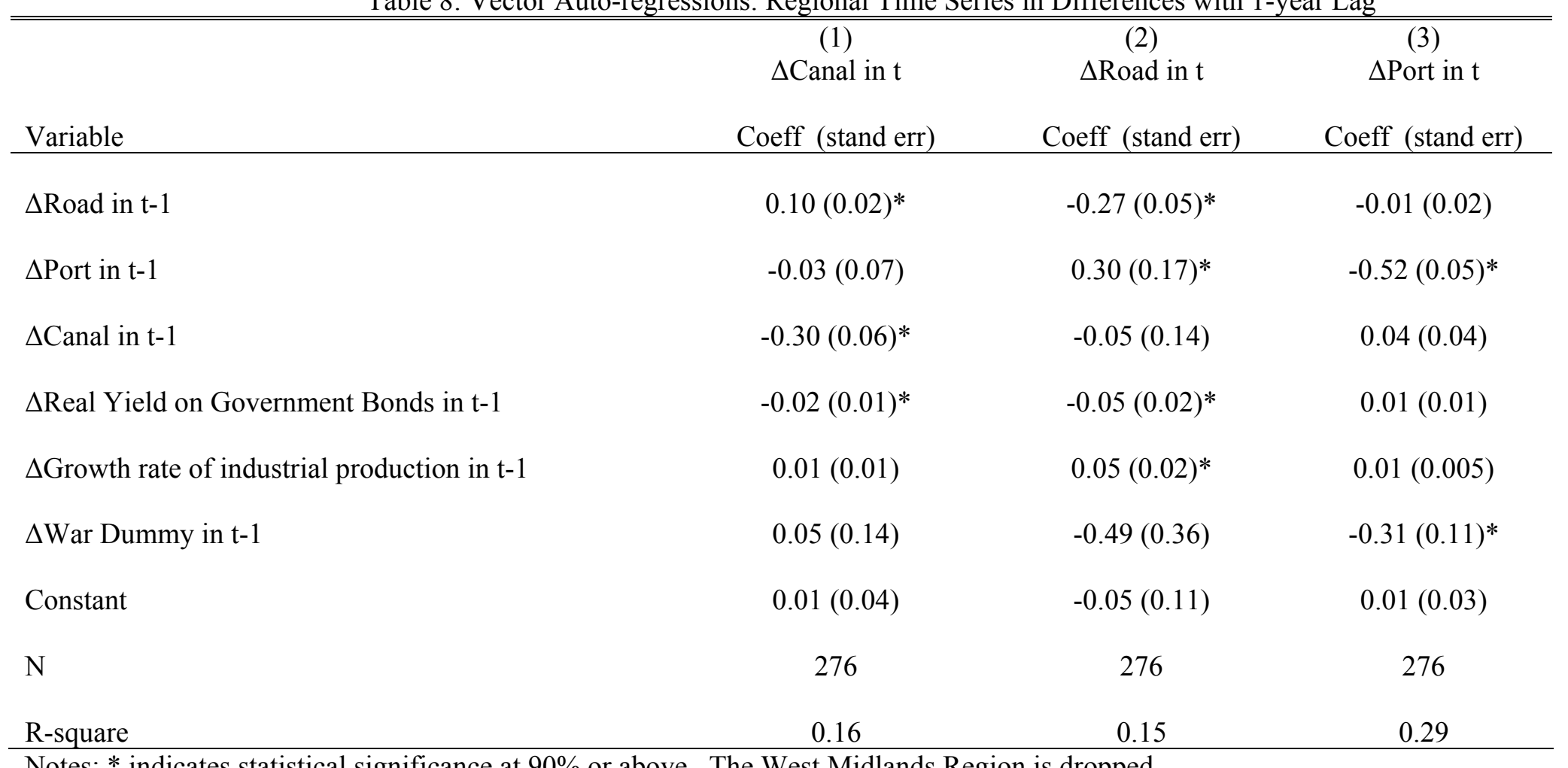

Notes: * indicates statistical significance at $90 \%$ or above. The West Midlands Region is dropped. 
An Act for continuing one Moiety of the Duties, granted by an Act of the eleventh and twelfth Year of King William the Third, for the Repair of Dover Harbour, and which have been, by several other Acts, continued till the twelfth Day of May one thousand seven hundred and sixty five; and for applying the same to completing and keeping in Repair the Harbour of Rye, in the County of Sussex, and for more effectually completing and keeping in Repair the said Harbour.

An Act for repairing, improving and better preserving of the Harbour and Quay of Wells, in the County of Norfolk.

An Act for clearing, depthening, repairing, maintaining and improving the Haven and Piers of Great Yarmouth; and for depthening and making more navigable the several

An Act for making and establishing public Quays or Wharfs at Kingston upon Hull, for the better securing His Majesty's Revenues of Customs, and for the Benefit of Commerce in the Port of Kingston upon Hull; for making a Bason or Dock, with Reservoirs, Sluices, Roads and other Works, for the Accommodation of Vessels using the said Port; and for appropriating certain Lands belonging to His Majesty, and for applying certain Sums of Money out of His Majesty's Customs at the said Port for those Purposes; and for

1774 establishing other necessary Regulations within the Town and Port of Kingston upon Hull.

1775 An Act for completing and maintaining the Pier at the Town of Mevagissey, in the County of Cornwall.

1785 An Act to enlarge the Term and Powers of several Acts relating to the Harbour of Liverpool; and for making Two additional Docks and Piers in or near the Port of Liverpool. An Act for rebuilding the Pier of Margate in the Isle of Thanet, in the County of Kent; for ascertaining, establishing and recovering certain Duties in lieu of the ancient and customary Droits, for the Support and Maintenance of the said Pier; for widening, paving, repairing, cleansing, lighting and watching the Streets, Lanes, Highways and Public Passages in the Town of Margate, and Parish of Saint John the Baptist, in the said Isle of Thanet; for settling the Rates of Porters, Chairmen, Carters and Carmen within the Act for preventing Encroachments, Nuisances and Annoyances therein.

An Act for repairing or rebuilding the Pier adjoining to the Harbour of Broadstairs in the Isle of Thanet in the County of Kent; and for the better preserving the said Harbour and

1792 for removing and preventing Obstructions, Nuisances and Annoyances, and regulating the mooring of Ships and Vessels within the said Harbour.

1792 An Act for further enlarging and improving the Harbour of Whitehaven in the County of Cumberland.

1792 An Act for making a Harbour in the Cove of Beer in the County of Devon.

1793 An Act for erecting and making a Pier and Harbour in the Cove of Trevaunance, in the Parish of Saint Agnes, in the County of Cornwall.

1794 An Act for better regulating the Harbour of Dover in the County of Kent.

1796 An Act for widening, deepening, enlarging, altering and improving the Haven of the Town and Port of Great Grimsby in the County of Lincoln.

An Act to enable the Lords of the Manor of Brixham in the County of Devon, to repair and enlarge, or rebuild the Pier or Quay at Brixham Quay, within the said Manor, to

1799 improve the Harbour there, to regulate the Moorings of Vessels therein, and to establish a Market there.

1800 An Act for making Wet Docks, Basons, Cuts and other Works, for the greater Accommodation and Security of Shipping, Commerce and Revenue, within the Port of London. An Act for building a Pier at Sheerness, in the Isle of Sheppy, in the County of Kent; for ascertaining, imposing and recovering certain Duties for the supporting, maintaining and keeping in Repair the said Pier; for paving, repairing, cleansing, lighting, watching, watering and improving the Highways, Streets, Lanes and other public Passages and Places, within that Part of the Parish of Minster, in the said Isle of Sheppy, (which lieth near His Majesty's Dock Yard and Garrison of Sheerness, ) called Blue Town and Mile 1801 Town; and for preventing Nuisances, Annoyances and Obstructions therein.

1801 An Act for more effectually improving and maintaining the old Harbour of Rye, in the County of Sussex.

1803 An Act for the further Improvement of the Port of London, by making Docks and other Works at Blackwall, for the Accommodation of the East India Shipping in the said Port. An Act to authorize the Advancement of further Sums of Money out of the Consolidated Fund, to be applied in the Improvement of the Port of London, by the Mayor, Aldermen and Commons of the City of London in Common Council assembled; and to empower the Lords Commissioners of His Majesty's Treasury to purchase the legal Quays

1803 between London Bridge and the Tower of London.

1803 An Act for repairing, enlarging and improving the Pier and Quay within the Port or Harbour of Torquay in the County of Devon

1803 An Act for improving and rendering more commodious the Port and Harbour of Bristol.

An Act for abolishing certain Dues called Petty Customs, Anchorage and Groundage, and for improving the Port of the Town of Southampton; for making a convenient Dock

1803 for the Security of Ships; for extending the Quays and Wharfs, and making Docks and Piers in the Harbour there; and for erecting Warehouses for the safe Custody of Goods 
and Merchandize; and for imposing certain Duties for the above Purposes.

1805

1808

1811

1811

1811

1811

1812

1813

1813

1816

1819

1819

1820

1821

1822

1823

1823

1824

1825

1825

1825

1825

1825

1827

1828

An Act for improving and rendering more commodious the Port of Ipswich, in the County of Suffolk.

An Act for completing the Improvement of the Port of Bristol.

An Act for maintaining and improving the Docks and Warehouses, called the Commercial Docks, and for making and maintaining other Docks and Warehouses to

communicate therewith, all in the Parish of Saint Mary Rotherhithe, in the County of Surrey.

An Act for making a Harbour and Wet Dock, at or near Saint Nicholas Bay, in the Parish of Saint Nicholas and All Saints, in the Isle of Thanet, in the County of Kent; and for making a Navigable Canal from the said Harbour to the City of Canterbury.

An Act for the Improvement of the Port and Town of Liverpool, and amending the several Acts relating to the Docks, Quays and other Works belonging to the said Port.

An Act for constructing a Harbour at Porthleven in Mounts Bay, in the County of Cornwall.

An Act for the Improvement of the Harbour of Sutton Pool in the Port of Plymouth, in the County of Devon.

An Act for the Improvement of certain Parts of the Harbour of Catwater within the Manor of Plympton in the County of Devon; and for the more effectually providing for the

Security of the Communication from Pamphlet Point across the contiguous Water of Lary within the said Manor.

An Act for improving the Port and Harbour of Boston, in the County of Lincoln; and for fixing the Wharsage of Goods landed within the said Port and Harbour; and for better maintaining the Buoys, Beacons, and Seamarks, belonging thereto.

An Act for improving the Pier and Port of Hartlepool, in the County of Durham.

An Act for the further Improvement of the Harbour of Wexford.

An Act for the more effectual Security and Improvement of the Harbour of New Shoreham, in the County of Sussex.

An Act for improving the Harbour of Blakeney, within the Port of Blakeney and Clay, in the County of Norfolk.

An Act for improving the Lighthouse on the Isle of Anglesea, belonging to the Trustees of the Liverpool Docks, and for further amending the Acts relating to the Docks and Harbour of Liverpool.

An Act for improving the Harbour of Bude, in the County of Cornwall; and for making and maintaining a Navigable Canal from the said Harbour of Bude to or near the Village of Ane County of Devon, and divers Branches therefrom, all in the said Counties of Cornwall and Devon.

An Act for completing and maintaining the Harbour, Quay or Pier, at the Village of Goran Haven, in the Parish of Goran in the County of Cornwall.

An Act for improving and maintaining the Harbour, Pier or Cobb at the Port and Borough of Lyme Regis, in the County of Dorset.

An Act for erecting and maintaining a Chain Pier and other Works connected therewith, at the Town of Brighthelmston, in the County of Sussex

An Act for the Improvement, more effectual Security and Maintenance of the Harbour of Bridport in the County of Dorset.

An Act for more effectually improving and keeping in repair the Pier and Harbour of Minehead in the County of Somerset.

An Act for completing the Port or Harbour of Courtown, at Brenogue Head, in the County of Wexford.

An Act for making and constructing certain Wet Docks, Warehouses and other Works, for the Accommodation and better Security of Ships and other Vessels in the Coal and other Trades, in the Isle of Dogs, in the Parish of All Saints Poplar, in the County of Middlesex.

An Act for making and constructing certain Wet Docks, Warehouses and other Works, in the Parish of Saint Botolph without Aldgate, and in the Parish or Precinct of Saint Katharine, near the Tower of London, in the County of Middlesex.

An Act for making Wet Docks, Warehouses and other Works, in and near to Saint Saviour's Dock, in the Parishes of Saint John Southwark, and Saint Mary Magdalen Bermondsey, in the County of Surrey, to be called The South London Docks.

An Act for the further Improvement of the Port and Harbour and Town of Liverpool, and for altering, extending and amending the several Acts relating thereto.

An Act for making and constructing a Harbour and other Works, in the Parish of Sidmouth, in the County of Devon.

An Act for the more effectual repairing, maintaining, and improving the Piers and Harbour of the Town and Port of Whitby in the County of York.

An Act for rebuilding, or for improving, regulating, and maintaining, the Town Quay of Gravesend in the County of Kent, and the Landing Place belonging thereto. 
An Act for more effectually maintaining and improving the Harbour of Dovor in the County of Kent.

1829 An Act for making and maintaining a Pier at or near Southend in the Parish of Prittlewell in the County of Essex, and for making convenient Approaches to and from the same.

1829 An Act for maintaining the Pier at Sheerness in the Parish of Minster, in the Isle of Sheppy, in the County of Kent.

1830 An Act for maintaining and governing the Harbour of Axmouth, and Works connected therewith, in the Parish of Axmouth in the County of Devon.

1830 An Act for more effectually improving the Harbour of Southwold in the County of Suffolk. 
An Act to enable the most noble Francis Duke of Bridgewater, to make a navigable Cut or Canal from Longford Bridge, in the Township of Stretford, in the County Palatine of Lancaster, to the River Mersey, at a Place called The Hemp Stones, in the Township of Halton, in the County of Chester.

An Act for making and maintaining a navigable Cut or Canal from the River Severn, between Bewdley and Titton Brook, in the County of Worcester, to cross the River Trent, at

An Act for making and maintaining a navigable Cut or Canal from Birmingham to Bilstone, and from thence to Autherley, there to communicate with the Canal now making

1768 between the Rivers Severn and Trent; and for making collateral Cuts up to several Coal Mines.

An Act for making and maintaining a navigable Canal from the City of Coventry, to communicate upon Fradley Heath, in the County of Stafford, with a Canal now making

1768 between the Rivers Trent and Mersey.

An Act for making and maintaining a navigable Cut or Canal from the River Severn, at or near a Place called Hawford, in the Parish of Claines, in the County of Worcester, to

or near a Place called Chapel Bridge, within the Borough of Droitwich, in the said County.

An Act to rectify a Mistake in an Act passed in the Eighth Year of His present Majesty, intituled, An Act for making and maintaining a navigable Cut or Canal from Birmingham to Bilstone, and from thence to Autherley, there to communicate with the Canal now making between the Rivers Severn and Trent; and for making collateral Cuts up to several

1769 Coal Mines; and to explain and amend the said Act.

1769 An Act for making and maintaining a navigable Canal, from the Coventry Canal Navigation to the City of Oxford.

An Act for making and maintaining a navigable Cut or Canal from Leeds Bridge, in the County of York, to the North Lady's Walk in Liverpool, in the County Palatine of

1770 Lancaster, and from thence to the River Mersey.

An Act for making a navigable Cut or Canal from Chesterfield, in the County of Derby, through or near Worksop and Retford, to join the River Trent, at or near Stockwith, in the

1771 County of Nottingham.

1771 An Act for making a navigable Cut or Canal from Bradford to join the Leeds and Liverpool Canal at Windhill, in the Township of Idle, in the County of York.

An Act to enable the Right Honourable Sackville Earl of Thanet to make a navigable Cut or Canal from a Place called The Spring, lying near Skipton Castle, in the County of

1772 York, to join to and communicate with the navigable Canal from Leeds to Liverpool, in a Close called Hebble End Close, in the Township of Skipton, in the said County of York.

1772 An Act for making a Navigable Cut or Canal from the River Dee, within the Liberties of the City of Chester, to or near Middlewich and Nantwich, in the County of Chester. An Act for making and continuing a navigable Cut or Canal from Maugan Porth, through the several Parishes of Maugan Saint Colomb Major, Little Colan, and Saint Colomb

1773 Minor, to Lower Saint Colomb Porth, in the County of Cornwall.

An Act for making a navigable Cut or Canal, from the Port or Harbour of Bude, in the Hundred of Stratton, in the County of Cornwall, to the River Tamer, in the Parish of

1774 Calstoke, in the said County.

An Act for enabling Sir John Ramsden Baronet, to make and maintain a navigable Canal, from the River Calder (between a Bridge called Cooper's Bridge and the Mouth of the River Colne) to The King's Mill, near the Town of Huddersfield, in the West Riding of the County of York. 1775 Newcastle under Lyme, in the County of Stafford.

An Act to enable the Company of Proprietors of the Navigation from the Trent to the Mersey, to make a navigable Canal from the said Navigation, on the South Side of

1776 Harecastle, in the County of Stafford, to Froghall, and a Rail Way from thence to or near Caldon, in the said County; and to make other Rail Ways.

An Act for making and maintaining a navigable Canal within and from certain Lands, belonging to Thomas Talbot Foley Esquire, in the Parish of Dudley, in the County of Worcester, to join and communicate with the Stourbridge Navigation, at a Place called Black Delph, upon Pensnet Chase, in the Parish of Kingswinford, in the County of 1776 Stafford.

An Act for making and maintaining a navigable Canal from or near the Town of Stourbridge, in the County of Worcester, to join the Staffordshire and Worcestershire Canal, at or near Stourton, in the County of Stafford; and also Two collateral Cuts, one from a Place called The Fens upon Pensnet Chace, to communicate with the intended Canal near the Junction of Wordesley Brook with the River Stour; and the other from a Place called Black Delph, upon the said Chace, to join the first mentioned collateral Cut at or

1776 near certain Lands called The Lays, in the Parish of Kingswinford, in the said County of Stafford. 
An Act for making and maintaining a navigable Cut or Canal from the River Trent, in the Lordships of Sawley and Long Eaton, in the County of Derby, to or near Langley

An Act for making a Navigable Canal from the Town of Basingstoke, in the County of Southampton, to communicate with the River Wey, in the Parish of Chertsey, in the

An Act to explain, amend and render more effectual, an Act, made in the sixteenth Year of the Reign of His present Majesty, for making and maintaining a Navigable Canal from or near the Town of Stourbridge, in the County of Worcester, to join the Staffordshire and Worcestershire Canal at or near Stourton, in the County of Stafford; and also

1782 two collateral Cuts therein mentioned.

An Act to amend and render more effectual several Acts passed in the Sixth, Tenth, Fifteenth and Sixteenth Years of the Reign of His present Majesty, for making a navigable

Canal from the Trent to the Mersey; and a Branch from the said Canal to Froghall, and a Railway from thence to or near Caldon, in the County of Stafford.
An Act for making and maintaining a Navigable Canal from a Place near Rider's Green, in the County of Stafford, to Broadwater Fire Engine, and Six Collateral Cuts from the same, to several Coal Mines; and also a Navigable Canal from or near the Town of Birmingham, to join the Coventry Canal at or near Fazeley, in the Parish of Tamworth, in the said County of Stafford, with a Collateral Cut to the lower Part of the said Town of Birmingham.

An Act for making and maintaining a Navigable Canal from the River Thames or Isis, at or near Leachblade, to join and communicate with the Stroudwater Canal at Walbridge, near the Town of Stroud; and also a Collateral Cut from the said Canal at or near Siddington, to or near the Town of Cirencester, in the Counties of Gloucester and Wilts. An Act to enable the Company of Proprietors of the Navigation from The Trent to The Mersey, and the Company of Proprietors of the Navigation from Birmingham to Fazely, to make a navigable Canal from the said Trent and Mersey Navigation, on Fradley Heath in the County of Stafford, to Fazely, in the said County; and for confirming certain

1785 Articles of Agreement entered into between the said Trent and Mersey, the Oxford and the Coventry, Canal Navigation Companies.

1785 An Act extending the Dudley Canal to the Birmingham Canal, at or near Tipton Green, in the County of Stafford.

An Act for making and maintaining a navigable Canal, from the Canal at Donnington Wood in the County of Salop, to or near a Place called Southall Bank, and from thence by two several Branches to communicate with the River Severn, one near Coalbrook Dale, and the other near Madeley Wood in the said County, and also certain collateral Cuts 1788 to join such Canal.

An Act for making and maintaining a navigable Canal from or from near to Cromford Bridge in the County of Derby to join and communicate with the Erewash Canal, at or near Langley Bridge; and also a Collateral Cut from the said intended Canal at or near Codnor Park Mill, to or near Pinxton Mill in the said County.

An Act for making and maintaining a navigable Canal from or near the Borough of Andover in the County of Southampton, to or near Redbridge, in the Parish of Millbrook, in 1789 the said County.

An Act to alter and amend an Act passed in the last Session of Parliament, for making and maintaining a Navigable Canal from or near to Cromford Bridge in the County of Derby, to join and communicate with the Erewath Canal, at or near Langley Bridge; and also a collateral Cut from the said intended Canal at or near Codnor Park Mill, to or

1790 near Pinxton Mill in the said County.

An Act to enable the Company of Proprietors of the Canal Navigation from Leeds to Liverpool, to vary the Line of the said Canal Navigation; and to raise a further Sum of

Money for the Purpose of completing the said Canal Navigation; and for other Purposes.

An Act for making and maintaining a navigable Cnaal from or from near to the Town of Birmingham in the County of Warwick, to communicate with the River Severn, near to

1791 the City of Worcester.

An Act for making and maintaining a navigable Communication between the Loughborough Canal and the Town of Leicester, and for making and maintaining a

Communication by Railways or Stone Roads, and Water Levels, from several Places and Mines to the said Loughborough Canal, and for continuing the same, by passing

1791 along the said Canal to the said navigable Communication, all in the County of Leicester.

An Act for making and maintaining a navigable Canal from Kington, in the County of Hereford, by or through Leominster, to join the River Severn near Stourport Bridge, in the

1791 County of Worcester.

An Act for making and maintaining a navigable Cut or Canal from the City of Hereford to the City of Gloucester, with a collateral Cut from the same to the Town of Newent in

1791 the County of Gloucester.

An Act for making and maintaining a navigable Canal from Manchester to or near Presto lee Bridge, in the Township of Little Lever, and from thence, by one Branch, to or near

1791 the Town of Bolton, and by another Branch to or near the Town of Bury, and to Wedel Brook, in the Parish of Bury, all in the County Palatine of Lancaster.

An Act for enlarging and improving the Canal called Tattershall Canal, from the River Witham to the Town of Tattershall, and extending the same into the River Bain, and for making the said River Bain navigable from thence to or into the Town of Horncastle, all in the County of Lincoln; and also for amending and rendering complete the Navigable Communication between the said River Witham and the Fosdike Canal, through the High Bridge in the City of Lincoln.

An Act for making and maintaining a Navigable Canal, from or from near Wyrley Bank in the County of Stafford, to communicate with the Birmingham and Birmingham and

1792 Fazeley Canal, at or near the Town of Wolverhampton in the said County; and also certain Collateral Cuts therein described, from the said intended Canal. 
An Act for making and maintaining a Navigable Canal from the Cromford Canal in the County of Nottingham, to or near to the Town of Nottingham, and to the River Trent near

An Act for making and maintaining a Navigable Canal from the Foot of Coombe Hill in the Parish of Leigh in the County of Gloucester, to join the River Severn, at or near a

1792 An Act for making a Navigable Canal from Manchester to or near Ashton under Line, and Oldham in the County Palatine of Lancaster.

An Act for making and maintaining a Navigable Canal from Kirkby Kendal in the County of Westmorland, to West Houghton in the County Palatine of Lancaster; and also a Navigable Branch from the said intended Canal at or near Borwick, to or near Warton Cragg; and also another Navigable Branch from, at or near Gale Moss, by Chorley, to or near Daxbury in the said County Palatine of Lancaster.

An Act for making and maintaining a Navigable Canal from or nearly from the Town of Grantham in the County of Lincoln, to the River Trent, near Nottingham Trent Bridge; and also a Collateral Cut from the said intended Canal, at or near Cropwell Butler, to the Town of Bingham, both in the County of Nottingham.

1793 County.

An Act for making and maintaining a Navigable Canal from the North End of the Shropshire Canal in the Township of Rockwardine Wood, in the County of Salop, to the Town of Shrewsbury in the said County.

An Act for making and maintaining a Navigable Canal from the Oxford Canal Navigation at Braunston, in the County of Northampton, to join the River Thames at or near

1793 Bratford in the County of Middlesex, and also certain Collateral Cuts from the said intended Canal.

An Act for making and maintaining a navigable Canal from or nearly from a Place called The Saltisford, in the Parish of Saint Mary in the Borough of Warwick, unto or near to the Parish of Birmingham in the County of Warwick, and to terminate at or near to a certain navigable Canal in or near to the Town of Birmingham, called the Digbeth Branch

1793 of the Birmingham and Birmingham and Fazeley Canal Navigations.

An Act for making and maintaining a Navigable Canal from the River Trent, at or near Swarkstone Bridge, to and through the Borough of Derby, to Little Eaton, with a Cut out of the said Canal in or near the said Borough, to join the Erewash Canal near Sandiacre, and for making Rail Ways from such Canal to several Collieries in the Parishes or

1793 Liberties of Denby, Horsley and Smalley, all in the County of Derby.

An Act for making and maintaining a Navigable Canal from the Dudley Canal in the County of Worcester, to the Worcester and Birmingham Canal now making at or near Selly

1793 Oak in the said County; and also certain Collateral Cuts to communicate therewith

An Act for making and maintaining a Navigable Canal from the Collieries at Shipley and Westhallam in the County of Derby, to the Erewash Canal in the Parish of Stanton by

1793 Dale, in the said County.

1793 An Act for making and maintaining a Navigable Cut or Canal from the Melton Mowbray Navigation in the County of Leicester, to Oakham in the County of Rutland. An Act for making and maintaining a Navigable Canal from the Worcester and Birmingham Canal Navigation, in the Parish of King's Norton, into the Borough of Stratford upon

1793 Avon; and also certain Collateral Cuts from the said intended Canal.

An Act for making and maintaining a Navigable Canal from the River Severn, at or near the City of Gloucester, into a Place called Berkley Pill in the Parish of Berkeley; and

1793 also a Cut to or near the Town of Berkeley in the County of Gloucester.

An Act for making and maintaining a Navigable Cut or Canal from a Place called Hammerside Hill, in the Parish of Ulverstone in the County Palatine of Lancaster, to a Place

1793 called Weint End, near the Town of Ulverstone aforesaid.

An Act for making and maintaining a Navigable Canal from the River Dun Navigation Cut, at or near Stainforth in the West Riding of the County of York, to join and communicate with the River Trent at or near Keadby in the County of Lincoln, and also a Collateral Cut from the said Canal to join the said River Dun, in the Parish of Thorne

1793 in the said Riding.

An Act to enable the Company of Proprietors of the Canal Navigation from Manchester to or near Ashton under Lyne and Oldham, to extend the said Canal from a Place called Clayton Demesne, in the Township of Droylsden, in the Parish of Manchester aforesaid, to a Place in the Turnpike Road in Heaton Norris, leading between Manchester and Stockport, opposite to the House known by the Sign of The Three Boars Heads; and from or nearly from a Place called Taylor's Barn, in the Township of Reddish to Denton, at a Place called Beat Bank, adjoining the Turnpike Road leading between Stockport and Ashton under Lyne; and also from the intended Aqueduct Bridge, at or near a Place called Waterhouses, in the Parish of Ashton under Lyne aforesaid, to a Place called Stake Leach, at Hollinwood, in the Township of Oldham aforesaid.

An Act for making and maintaining a Navigable Canal from the River Calder, in the Township of Warmfield cum Heath, to or near the Town of Barnsley, and from thence to 列

An Act for making and maintaining a Navigable Canal from the River Dun Navigation Cut, in the Township of Swinton, to or near the Town of Barnsley in the Parish of

1793 Silkstone, in the West Riding of the County of York; and certain Collateral Cuts branching out of the said Canal. 
An Act for making and maintaining a Navigable Canal from the River Severn at Shrewsbury in the County of Salop, to the River Mersey at or near Netherpeol in the County of

An Act to alter and amend an Act, passed in the last Session of Parliament, intituled, An Act for making and maintaining a Navigable Canal from Kirkby Kendal, in the County of Westmoreland, to West Houghton, in the County Palatine of Lancaster: and also a Navigable Branch from the said intended Canal, at or near Borwick, to or near Warton Cragg: and also another Navigable Branch from, at or near Gale Moss, by Chorley, to or near Duxbury in the said County Palatine of Lancaster; and also for making a

1793 Navigable Branch from the said Canal, at or near Galgate, to Glasson Dock in the said County Palatine of Lancaster.

An Act to vary and extend the Line of the Canal authorized to be made by an Act passed in the thirty first Year of the Reign of His present Majesty, intituled, An Act for making and maintaining a Navigable Canal from the City of Hereford to the City of Gloucester, with a Collateral Cut from the same to the Town of Newent, in the County of Gloucester,

1793 and to amend the said Act.

An Act for making and maintaining a Navigable Canal from Wisbech River, at or near a Place called the Old Sluice in the Town of Wilbech in the Isle of Ely and County of Cambridge, to join the River Nene in the Parish of Outwell in the said Isle of Ely, and in the County of Norfolk, and for improving and maintaining the Navigation of the said

1794 River from Outwell Church to Salter's Load Sluice.

An Act for making and maintaining a Navigable Canal from the Coventry Canal at or near Marston Bridge in the Parish of Bedworth in the County of Warwick, to a certain Close in the Parish of Asbby de la Zouch in the County of Leicester, and for continuing the same from thence in one Line to the Limeworks at Ticknall in the County of Derby,

1794 and in another Line to the Lime Works at Cloudhill in the said County of Leicester, with certain Cuts or Branches from the said Canal.

1794 An Act for extending the Wyrley and Essington Canal.

An Act for making a Navigable Canal from or near Porthywain Lime Rocks, in the Parish of Llanyblodwell in the County of Salop, to or near Newton in the County of

1794 Montgomery; and also certain Collateral Cuts from the said Canal.

An Act for making certain Navigable Cuts from the Towns of Buckingham, Aylesbury and Wendover, in the County of Buckingham, to communicate with the Grand Junction

1794 Navigation, authorized to be made by an Act of the last Session of Parliament; and for amending the said Act.

An Act for making and maintaining a Navigable Canal out of and from the Warwick and Birmingham Canal, now cutting or intended to be cut in the Parish of Badbrooke in the

1794 County of Warwick, into the Oxford Canal, in the Parish of Braunston in the County of Northampton.

1794 An Act for extending and improving the Birmingham Canal Navigations.

An Act for making a Navigable Canal from the River Kennet, at or near the Town of Newbury in the County of Berks, to the River Avon at or near the City of Bath, and also

1794 certain Navigable Cuts therein described.

An Act for making and maintaining a Navigable Canal, with certain Rail Ways and Stone Roads from several Collieries in the County of Somerset, to communicate with the

An Act for making and maintaining a Navigable Canal from the Calder Navigation, at or near Sowerby Bridge Wharf, in the Parish of Halifax in the West Riding of the County of York, to join the Canal of his Grace the Duke of Bridgewater, in the Parish of Manchester in the County Palatine of Lancaster; and also certain Cuts from the said intended

1794 Canal.

An Act for making and maintaining a Navigable Canal from or nearly from Bury Bridge in the Parish of Bury, by Haslingden, to or nearly to Church Kirk, all in the County

1794 Palatine of Lancaster.

An Act for making and maintaining a Navigable Canal from and out of the Canal of Sir John Ramsden Baronet, at or near the Town of Huddersfield in the West Riding of the County of York, to join and communicate with the Canal Navigation from Manchester to or near Ashton under Lyne and Oldham, at or near the Town of Ashton under Lyne

1794 aforesaid, in the County Palatine of Lancaster.

An Act to enable the Company of Proprietors of the Canal Navigation from Leeds to Liverpool to complete the said Navigation, and to vary the Line thereof, and to raise a

1794 further Sum of Money for those Purposes; and for making a Navigable Branch therein described from the intended new Line of the said Canal.

An Act for making and maintaining a Navigable Canal from and out of the Canal Navigation from Manchester to or near Ashton under Lyne and Oldham in the County Palatine of Lancaster, at the intended Aqueduct Bridge in Dukinfield in the County of Chester, at or near to Chapel Milton in the County of Derby; and a Communication by Rail Ways or Stone Roads from thence to Load's Knowl, within Peak Forest in the said County of Derby; and a Branch from and out of the said intended Canal to Whaley Bridge in the said 1794 County of Chester.

An Act for authorizing the Company of Proprietors of the Grand Junction Canal to vary the Course of a certain Part of the said Canal in the County of Hertford, so as to render the Navigation thereof more safe and convenient; and for making some other Amendments and Alterations in an Act made in the thirty third Year of the Reign of His present

1795 Majesty, for making the said Canal.

1795 An Act for making and extending a Navigable Cut from the Town of Watford in the County of Hertford, to the Town of Saint Alban in the same County. 
An Act for making a Navigable Cut from the Stratford upon Avon Canal in the Parish of Lapworth, into the Warwick and Birmingham Canal in the Manor of Kingswood in the

An Act for making a Navigable Cut from the Grand Junction Canal in the Precinct of Norwood in the County of Middlesex to Paddington in the said County.

An Act for making and maintaining a Navigable Canal from the Town and County of the Town of Southampton to the City of New Sarum in the County of Wilts, with a Collateral Branch to Northam within the Liberties of the Town of Southampton.

1795 Lancaster, to the Township of Pennington near the Town of Leigh in the said County.

An Act for authorizing the Company of Proprietors of the Warwick and Braunston Canal Navigation to vary the Course of a certain Part of the said Canal, and for amending

and altering the Act made in the thirty fourth Year of the Reign of His present Majesty, for making the said Canal.

An Act to vary and alter the Line of the Canal, authorized to be made by an Act, passed in the thirty fourth Year of the Reign of His present Majesty, intituled, An Act for making a Navigable Canal from the River Kennet, at or near the Town of Newbury, in the County of Berks, to the River Avon, at or near the City of Bath; and also certain Navigable

An Act to vary and alter the Line of a Canal authorized to be made by an Act passed in the thirty fourth Year of the Reign of His present Majesty, intituled, An Act for making and maintaining a Navigable Canal, with certain Rail Ways and Stone Roads, from several Collieries in the County of Somerset, to communicate with the intended Kennett and

1796 Avon Canal in the Parish of Bradford, in the County of Wilts, and to alter and amend the said Act.

An Act for making a Navigable Canal from the River Exenear the Town of Topsham, in the County of Devon, to the River Tone, near the Town of Taunton, in the County of

Somerset; and for cleansing and making navigable a certain Part of the said River Tone; and for making certain Cuts from the said Canal.

An Act for making a Navigable Canal from near Gain's Cross in the Parish of Shillingstone Okeford, in the County of Dorset, to communicate with the Kennet and Avon Canal

Actho

An Act to explain and amend an Act, passed in the thirty third Year of the Reign of His present Majesty, intituled, An Act for making and maintaining a Navigable Canal from the River Severn at Shrewsbury, in the County of Salop, to the River Mersey at or near Netherpool in the County of Chester, and also for making and maintaining certain Collateral Cuts from the said intended Canal; and for varying and altering certain Parts of the Course of the said Canal and Collateral Cuts between Ruabon and Chester, and

1796 for making and maintaining several other Branches and Collateral Cuts to communicate therewith.

An Act to explain and amend an Act passed in the thirty third Year of the Reign of His present Majesty, intituled, An Act for making and maintaining a Navigable Canal from the River Severn at Shrewsbury, in the County of Salop, to the River Mersey at or near Netherpool, in the County of Chester, and also for making and maintaining certain Collateral Cuts from the said intended Canal; and for varying and altering certain Parts of the Whitchurch Line of the said Canal and Collateral Cuts, and for extending the same from Franckton Common to Sherryman's Bridge, in the Parish of Whitchurch, in the said County of Salop, and for making and maintaining several other Branches and

1796 Collateral Cuts to communicate therewith.

An Act for enabling the Company of Proprietors of the Grantham Canal Navigation, to finish and complete the same, and the Collateral Cut to communicate therewith; and for amending the Act of Parliament passed in the thirty third Year of the Reign of His present Majesty, for making and maintaining the said Canal and Collateral Cut.

1797 An Act to enable the Company of Proprietors of the Navigation from the Trent to the Mersey, to extend several Branches of Canal from and out of their said Navigation An Act to enable the Company of Proprietors of the Navigation from the Trent to the Mersey, to make a Navigable Canal from and out of a certain Branch of their said Navigation called The Caldon Canal, at or near Endon, to or near the Town of Leek in the County of Stafford; and also a Reservoir for supplying the several Canals of the said 1797 Company with Water.

An Act for authorizing the Company of Proprietors of the Gloucester and Berkeley Canal Navigation to vary the Line of a certain Part of the said Canal, so as to render the Execution thereof more easy, expeditious, and less expensive; and for altering and amending an Act passed in the thirty third Year of the Reign of His present Majesty, for

An Act for making and maintaining a Navigable Canal from Guinea Port in the Parish of Saint Breock, in the County of Cornwall, to Dunmeer Bridge in the Parish of Bodmin in the said County; and also a certain Collateral Cut from Cotton Wood to or near to Ruthern Bridge in the said Parish of Bodmin.

An Act for making and maintaining a navigable Canal, or Canal and Inclined Plane or Railway, from and out of the Newcastle under Lyme Canal, to the Canal of Sir Nigel Bowyer Gresley Baronet, near the Town of Newcastle under Lyme and also another Branch of Canal, or Inclined Plane or Railway, from and out of the said last mentioned

1798 Canal, at or near Apedale, to certain Coal and other Works, all in the County of Stafford. 
An Act to vary the Line of the Kennet and Avon Canal authorized to be made by two Acts passed in the thirty fourth and thirty sixth Years of the Reign of His present Majesty, 1798 and also to extend the Powers of and to amend the said Acts.

An Act for amending and enlarging the Powers of an Act, passed in the thirty third Year of the Reign of His present Majesty, for making and maintaining a Navigable Canal from the River Dunn Navigation Cut, at or near Stainforth, in the West Riding of the County of York, to join and communicate with the River Trent, at or near Keadby, in the

1798 County of Lincoln; and also a Collateral Cut from the said Canal, to join the said River Dunn, in the Parish of Thorne, in the said Riding.

An Act for authorizing the Company of Proprietors of the Stratford upon Avon Canal Navigation, to vary the Course of certain Parts of the said Canal, directed to be made by an Act, passed in the thirty third Year of the Reign of His present Majesty, and also to make a Branch out of the said Canal, and also to vary the Course of a navigable cut directed to be made from the said Stratford upon Avon Canal, in the Parish of Lapworth, into the Warwick and Birmingham Canal in the Manor of Kingswood, in the County of

1799 Warwick, by another Act passed in the thirty fifth Year of the Reign of His present Majesty; and for amending the said Acts.

An Act for making and maintaining a Navigable Canal from the River Thames, near to the Town of Gravesend in the County of Kent, to the River Medway, at a Place called Nicholson's Ship Yard in the Parish of Frindsbury, in the said County; and also a certain Collateral Cut from White Wall in the said Parish, to the said River Medway. An Act for the better enabling the Company of Proprietors of the Rochdale Canal to raise Money for completing the said Canal, and to vary the Line of the said Canal, and to

1800 alter, explain and amend the Act passed in the thirty fourth Year of the Reign of His present Majesty, for making the said Canal.

An Act to enable the Dearne and Dove Canal Company to finish and complete the said Canal, and the several Collateral Cuts branching therefrom; and for explaining, amending and enlarging the Powers of an Act passed in the thirty third Year of the Reign of His present Majesty, for making and maintaining the said Canal and Collateral

1800 Cuts; and for increasing the Tolls thereby granted.

An Act to authorize the Company of Proprietors of the Ellesmere Canal to extend the said Canal from the Whitchurch Branch thereof, at or near certain Water Corn Mills called The New Mills, in the Parish of Whitchurch, in the County of Salop to and to communicate with the Chester Canal, in the Township of Stoke, in the Parish of Acton, in the

1801 County of Chester; and for altering and amending the several Acts passed for making and maintaining the said Ellesmere Canal.

An Act for making and maintaining a Navigable Canal from, or from near the Town of Croydon, in the County of Surrey, into the Grand Surrey Canal, in the Parish of Saint Paul, Deptford, in the County of Surrey, and for supplying the Towns of Croydon, Streatham and Dulwich, and the District called Norwood, in the Parish of Croydon, in the said

1801 County of Surrey, and the Town of Syndenham, in the County of Kent, with Water from the said Canal.

An Act for making and maintaining a Navigable Canal from the River Thames at or near a Place called Wilkinson's Gun Wharf, in the Parish of Saint Mary at Rotherbithe, in the County of Surrey, to the Town of Mitcham, in the Parish of Mitcham, in the said County; and also divers Collateral Cuts or Branches communicating from the same to certain

1801 Parishes and Places within the Counties of Surrey and Kent.

An Act for improving and extending the Navigation of the River Exe, from the public Quay at Exeter to the public Road adjoining Four Mills near Crediton, in the County of 作

1801 and for enabling Charlotta Bethell Widow, to make and maintain a Navigable Canal from the

Acven Carrs, in the East Riding of the County of York, to Leven Bridge in the said Riding. An Act for enabling the Company of Proprietors of the Somersetshire Coal Canal Navigation to vary and alter the Lines of the said Canal; to raise Money for completing the

An Act for making and maintaining a navigable Canal from and out of the River Tamar, at or near Morwellham Quay, to the Town of Tavistock; and also a certain Collateral Cut

1803 to lead from the said Canal to Mill Hill Bridge, in the County of Devon.

An Act for enabling the Company of Proprietors of the Thames and Medway Canal to vary the Line of the said Canal, and to raise a further Sum of Money for completing the said Canal, and the Works thereunto belonging, and for altering and enlarging the Powers of an Act, made in the Thirty ninth and Fortieth Year of the Reign of His present

1804 Majesty, for making the said Canal, and a Collateral Cut thereto.

An Act to enable the Company of Proprietors of the Leicestershire and Northamptonshire Union Canal to vary the Line of the said Canal, and to alter and amend the Powers of

1805 the Act passed for making the said Canal.

An Act to enable the Company of Proprietors of the Gloucester and Berkeley Canal to vary and alter the Line of a certain Part of the said Canal, and to enable the said Company to raise a further Sum of Money for carrying into Execution the several Acts for making the said Canal.

An Act to authorize the Advancement of further Sums of Money out of the Consolidated Fund to be applied in completing the Canal across the Isle of Dogs, and erecting other

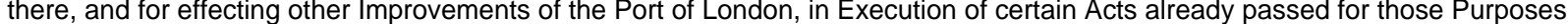

An Act to enable the Company of Proprietors of the Lancaster Canal Navigation, to vary the Course of the said Canal, and to make Railways or Roads, and to amend and

1807 render more effectual Two Acts relating to the said Navigation.

An Act for making a navigable Cut from the East Side of the River Tees near Stockton into the said River near Portrack in the County of Durham; and making various other 1808 Improvements in the Navigation of the said River between the Town of Stockton and the Sea. 
An Act for making and maintaining a Navigable Canal from the Union Canal, in the Parish of Gumley, in the County of Leicester, to join the Grand Junction Canal near Long

An Act to enable the Company of Proprietors of the Ellesmere Canal to extend the Whitchurch Line of the said Canal from Sherryman's Bridge to Castle Well, in the Town of

1810 passed in the Fortieth and Forty fourth Years of His present Majesty, for making the said Canal and a Collateral Cut thereto.

An Act to enable the Company of Proprietors of the Grand Surrey Canal to make a Collateral Cut, communicating therewith, in the Parish of Saint Mary Rotherbithe, in the

1811 County of Surrey, and to enable the said Company to complete the said Canal; and for amending the several Acts relating thereto.

An Act to vary and alter the Line of a Cut authorized to be made by an Act of the Thirty sixth Year of His present Majesty, for making a Canal from the River Exe near

1811 Topsham, in the County of Devon, to the River Tone near Taunton, in the County of Somerset; and to amend the said Act.

1811 An Act for making a navigable Canal between the Cities of Bath and Bristol, and also for supplying with Water the Inhabitants of the City of Bristol and its Neighbourhood. An Act for making a Navigable Canal from the River Avon, at or near Morgan's Pill, in the Parish of Easton in Gordano otherwise Saint George's, in the County of Somerset, to

1811 or near the River Tone, in the Parish of Saint James in Taunton, in the said County, and a certain navigable Cut therein described.

An Act for making and maintaining a navigable Canal with Aqueducts, Feeders and Reservoirs, from the Stort Navigation at or near Bishop's Stortford, in the County of

Hertford, to join the River Cam, near Clayhithe Sluice, in the County of Cambridge, with a navigable Branch or Cut from the said Canal at Sawston to Whaddon, in the County

1812 of Cambridge.

An Act for making a Navigable Canal from the Rivers Ant and Bure, at or near Wayford Bridge, near Dilham, to the Towns of North Walsham and Antingham, in the County of

1812 Norfolk.

An Act for making and maintaining a navigable Canal from The Grand Junction Canal in the Parish of Limehouse, with a Collateral Cut in the Parish of Saint Leonard

1812 Shoreditch, in the County of Middlesex.

An Act for making and maintaining a Navigable Canal from the River Medway, near Brandbridges in the Parish of East Peckham in the County of Kent, to extend to and unite with the Royal Military Canal in the Parish of Appledore in the said County; and also certain Navigable Branches and Railways from the said intended Canal.

An Act to authorize the Commissioners for improving and completing the Navigation of the Rivers Thames and Isis, from the Jurisdiction of the City of London, near Staines, in the County of Middlesex, to the Town of Cricklade, in the County of Wilts, to make a navigable Canal out of the River Thames near Milson's Point, in the Parish of Egham, in the County of Surrey, to communicate with the said River at or near Bell Weir, in the said Parish of Egham; and to erect Pound Locks in such Cut, with necessary Weirs and

1812 other Works on the said Navigation.

1813 An Act for making and maintaining a Navigable Canal, to unite the Rivers Wey and Arun, in the Counties of Surry and Sussex.

An Act for making and maintaining a Navigable Canal, from the Wilts and Berks Canal, in the Parish of Swindon, in the County of Wilts, to communicate with the Thames and Severn Canal in the Parish of Latton, in the same County.

An Act for making and maintaining a Navigable Canal from Newport Pagnell to The Grand Junction Canal, at Great Linford, in the County of Buckingham.

An Act for making and maintaining a navigable Canal from the River Derwent at East Cottingwith, in the East Riding of the County of York, to the Turnpike Road leading from

City of York to the Town of Kingston upon Hull, at a certain Place there, called Street Bridge, in the Township of Pocklington, in the said Riding.

An Act for establishing a Navigable Communication between the Birmingham Canal Navigations and the Worcester and Birmingham Canal, and amending certain Acts passed

1815 relative thereto

1815 An Act for making and maintaining a Navigable Canal from Sheffield to Tinsley, in the West Riding of the County of York.

An Act for making and maintaining a Navigable Canal from the River Arun to Chichester Harbour, and from thence to Langstone and Portsmouth Harbours, with a Cut or

1817 Branch from Hunston Common to or near the City of Chichester ; and for improving the Navigation of the Harbour of Langstone and Channels of Langstone and Thorney. An Act to enable the Grand Junction Canal Company to vary the Line of Part of their Canal in the County of Hertford, and for altering and enlarging the Powers of several Acts 1818 relating to the said Canal.

An Act to enable the Gloucester and Berkeley Canal Company to vary and alter the Line of their Canal; and for altering and enlarging the Powers of several Acts passed for 1818 making and maintaining the said Canal.

An Act to enable the Company of Proprietors of the Canal Navigation from Leeds to Liverpool, to make a Navigable Cut, and also a Collateral Branch or Railway, from their said Canal at Hennis Bridge near Wigan, to join the Duke of Bridgewater's Canal at Leigh, all in the County Palatine of Lancaster; and to amend the several Acts relating to the said Leeds and Liverpool Canal, and an Act for making the Rochdale Canal, so far as relates to certain Powers therein given to the late Duke of Bridgewater.

1819 An Act for making and maintaining a Navigable Canal from or from near the City of Carlisle, to the Solway Frith, at or near Fisher's Cross, in the Parish of Bowness, in the 
County of Cumberland

An Act to enable the Undertakers of the Navigation of the Rivers Aire and Calder, in the West Riding of the County of York, to make a Navigable Cut or Canal from and out of the said Navigation at Knottingley, to communicate with the River Ouze, near Goole, with Two Collateral Branches, all in the said Riding; and to amend the Acts relating to the 1820 said Navigation.

An Act to enable the Company of Proprietors of the Navigation from the Trent to the Mersey to make an additional Tunnel through Harecastle Hill in the County of Stafford, and an additional Reservoir in Knypersley Valley in the said County; and to amend and enlarge the Powers of the several Acts for making and maintaining the said Navigation, and the several Canals connected therewith.

An Act for making and maintaining a Navigable Canal from the River Lee Navigation in the Parish of Saint Mary Stratford Bow in the County of Middlesex, to join the Regent's the said County of Middlesex.

1824 Hammersmith, to the River Thames in the County of Middlesex, and for maintaining the same.

An Act to abridge, vary, extend and improve the Bristol and Taunton Canal Navigation, and to alter the Powers of an Act of the Fifty-first Year of His late Majesty for making the 1824 said Canal.

An Act for making and maintaining a navigable Cut or Canal from the River Adur, at or near Binesbridge, in the Parish of West Grinsted, in the County of Sussex, to Baybridge, 1825 in the said Parish.

An Act for making and maintaining a Canal for Ships and other Vessels, to commence at or near Seaton Bay, in the County of Devon, and terminating in the Bristol Channel, at Acar Stolford, or Bridgewater Bay, in the County of Somerset; with several collateral Branches to communicate therewith.

An Act for making and maintaining a navigable Canal from Tarras Pill, in the Parish of Duloe, in the County of Cornwall, to or near Moors Water, in the Parish of Liskeard in the 1825 said County, and for making several Roads to communicate therewith.

An Act to enable the Company of Proprietors of the Calder and Hebble Navigation to make a navigable Cut or Canal from Salterhebble Bridge to Bailey Hall, near to the Town 1825 of Halifax, in the West Riding of the County of York; and to amend the Act relating to the said Navigation. An Act for making and constructing a Canal from the Town of Alford in the County of Lincoln, to the Sea, at or near the Village of Anderby in the same County, with a Basin 1826 Harbour and Piers.

An Act for making a navigable Canal from the Staffordshire and Worcestershire Canal, in the Parish of Teitenhall in the County of Stafford, to the United Navigation of the 1826 Ellesmere and Chester Canals, in the Parish of Acton in the County Palatine of Chester.

An Act for making and maintaining a navigable Canal from the Peak Forest Canal, in the Township of Marple, in the County Palatine of Chester, to join the Canal Navigation

1826 from the Trent to the Mersey, at or near Harding's Wood Lock, in the Township or Hamlet of Talk, or Talk on the Hill, in the County of Stafford.

An Act for making and maintaining a navigable Communication for Ships and other Vessels between the City of Norwich and the Sea, at or near Lowestoft in the County of

1827 Suffolk.

An Act to enable the Company of Proprietors of the Birmingham and Liverpool Junction Canal Navigation to alter the Line of the said Navigation, and to make certain Branches 1827 therefrom, in the Counties of Stafford and Salop.

1829 An Act for altering, extending, and improving the Exeter Canal.

An Act to consolidate and amend the Acts relating to the Sankey Brook Navigation in the County of Lancaster, and to make a Navigable Canal from the said Navigation at

1830 Fidler's Ferry, to communicate with the River Mersey at Widness Wharf near Westbank in the Township of Widness in the said County. 
Figures

Figure 1: The Number of Road, Port, and Canal Improvement Acts in England, 1760-1830

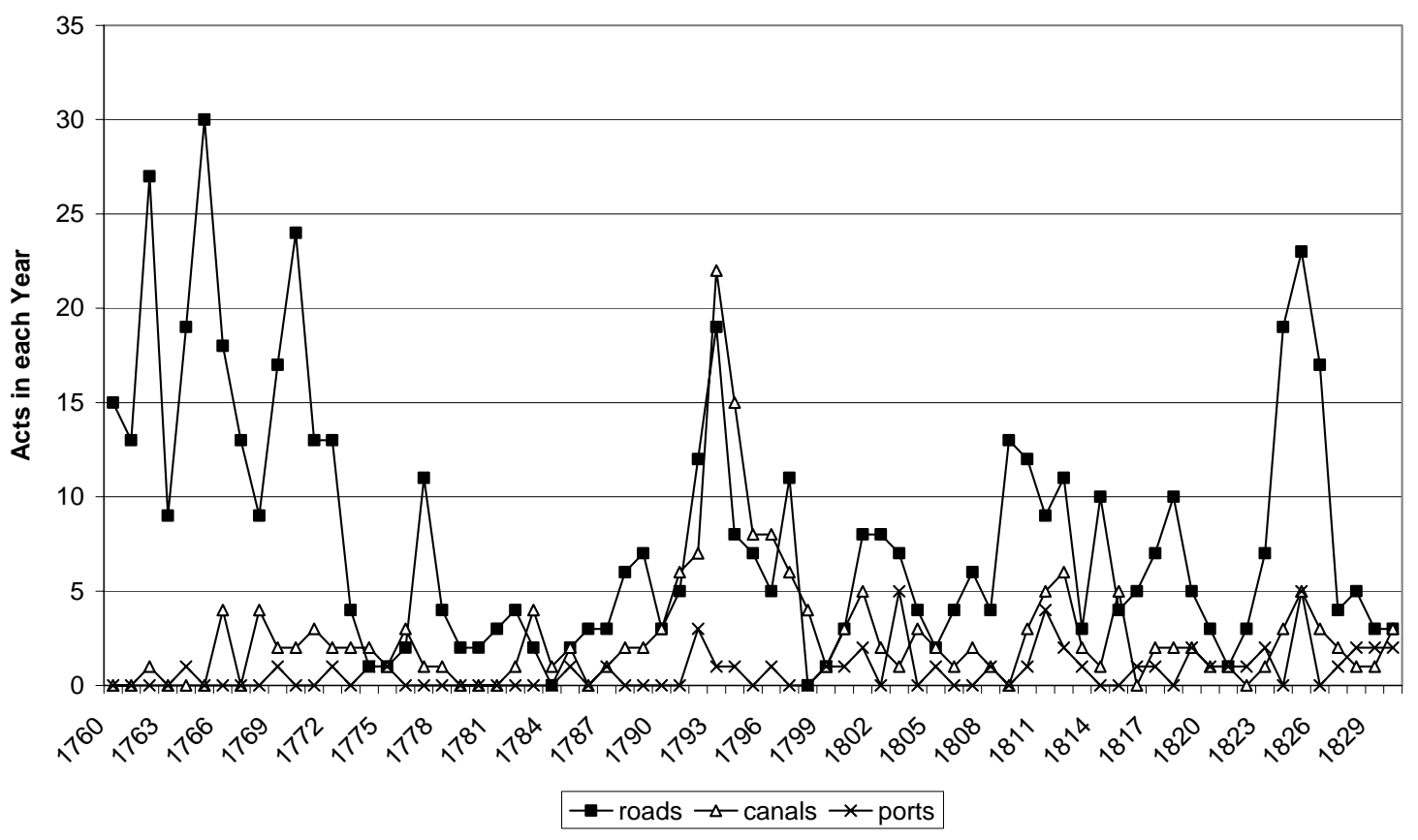

sources: see text. 